\title{
Transportes, modernização e formação regional - subsídios à história da era ferroviária em Minas Gerais, 1870-1940
}

\section{Transportation, modernization and regional formation - support for the study of the railway age in the State of Minas Gerais, Brazil, 1870-1940}

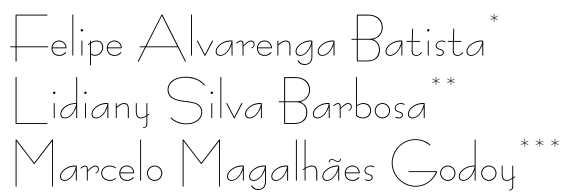

\section{Introdução}

Este trabalho apresenta panorama geral e avança questões sobre o processo de modernização dos transportes em Minas Gerais no período denominado era ferroviária mineira, que compreende os anos de 1870 a 1940. Parte-se de abordagem que combina, de um lado, noções histórico-estruturais e, de outro, especificidades da realidade regional. Essa postura metodológica deriva da compreensão de que o modelo de ferroviarismo efetivamente implantado em Minas Gerais não atendeu às reais necessidades da economia regional. De modo que, enquanto perdurou a ideologia legitimadora de que a ferrovia trazia consigo a própria modernidade, fim em si mesmo, e não meio de propulsão do desenvolvimento econômico, a modernização dos

\footnotetext{
* Mestrando em Economia Política Internacional pela UFRJ - Pesquisador do Centro de Planejamento e Desenvolvimento Regional - FACE/UFMG. E-mail: felipe_batista032@ hotmail.com

* Doutora em História Social pela UFRJ, Pesquisadora do Centro de Planejamento e Desenvolvimento Regional - FACE/UFMG. E-mail: lidiany@cedeplar.ufmg.br

**t Doutor em História Econômica pela USP, Professor do Departamento de Ciências Econômicas - FACE/UFMG, Pesquisador do Centro de Planejamento e Desenvolvimento Regional - FACE/UFMG. E-mail: mmgodoy@cedeplar.ufmg.br
} 
Transportes, modernização e formação regional - subsídios à história da era ferroviária ....

transportes em Minas Gerais teria atuado em desarmonia com a estrutura econômica.

No século XIX, a locomotiva era sinônimo inequívoco de modernidade ${ }^{1}$. Em decorrência disso, tratar de sua implantação era tratar da chegada do progresso. Entretanto, vale ressaltar que as ferrovias continuaram em expansão pelo território mineiro século XX adentro, quando, às justificativas típicas do XIX, acresceram-se outras. As estradas de ferro cobriram o espaço mineiro em extensão não observada em nenhuma outra região do Brasil. Entretanto, seus mais de $8.000 \mathrm{~km}$ de trilhos não integraram o mercado interno regional e, nesse sentido, foram incapazes de realizar o potencial instrumental que lhes é inerente. Embora ao longo de toda a era ferroviária mineira vozes dissonantes tenham alertado para o padrão de expansão que se adotava, certo véu alienante manteve a crença nos supostos beneficios imanentes à ferrovia até meados do século $\mathrm{XX}^{2}$, quando, desarticulada, com baixo sentido econômico e altamente custosa para os cofres públicos, a malha foi progressivamente desativada.

O texto está dividido em três tópicos, além desta introdução e das considerações finais. No primeiro, Capitalismo e modernização dos transportes são, resumidamente, discutidas as diferenças históricas da modernização dos transportes no centro e na periferia mundial. É abordada também a problemática da generalização de modelo de interpretação das transformações ocorridas no setor de transportes para as distintas regiões do Brasil. No segundo, Miopia politica e perda de substância, são discutidas as características histórico-estruturais de Minas Gerais e a inconsistência política da modernização ferroviária da região. Por fim, no terceiro, A era ferroviária mineira, traça-se sintese da história das companhias que operaram na região e

${ }^{1}$ HARDMAN, Francisco Foot. Trem fantasma: a modernidade na selva. São Paulo: Companhia das Letras, 1988. p. 187-203.

${ }^{2}$ Demonstração desta assertiva está no Plano de Recuperação Econômica e Fomento a Produção (MINAS GERAIS. Edição Fac-similar Comemorativa dos 20 anos de Elaboração. Belo Horizonte: 1967), conjunto de políticas públicas, elaborado no ano de 1947, pelo secretário de Agricultura Américo R. Gianetti, com objetivo de promover o desenvolvimento regional. No capítulo XVI do Plano, intitulado Transportes e subdividido em dois itens (a. Plano Rodoviário e $b$. Plano Ferroviário), para o problema das ferrovias, sugeriu-se ampla gama de políticas que visavam reverter a situação de perda de dinamismo e inadequação da malha ferroviária. No Plano não há nenhuma sugestão sobre a desativação de linhas em operação. 
são destacadas as características essenciais do período. A partir da compilação de dados da expansão da malha, é apresentada proposta de periodização para a era ferroviária de Minas Gerais. As principais fontes primárias utilizadas neste estudo são Mensagens de Presidente de Provincia e de Estado, Anuários Estatísticos de Minas Gerais e do Brasil e Anais da Assembleia Legislativa da Província de Minas Gerais.

\section{Capitalismo e modernização dos transportes no centro e na periferia}

O desenvolvimento da indústria de transporte, compreendida enquanto indústria autônoma atuante na e para a esfera da circulação, embora integrante e necessária à esfera da produção, deve ser analisado no bojo do processo de surgimento, maturação e expansão do modo capitalista de produção ${ }^{3}$. A modernização dos transportes, que tem as ferrovias e os navios a vapor como grandes ícones, se mostrou indissociável da expansão capitalista nos países centrais e periféricos. Há, todavia, uma significativa diferença dos processos ocorridos em cada um deles. As ferrovias integram-se à denominada Segunda Revolução dos Transportes ${ }^{4}$, juntamente com a navegação a vapor e, por sua vez, correspondem à Segunda Revolução Industrial. As transformações nesta revolução dos transportes permitiram o aumento da velocidade e da qualidade do transporte de carga, o barateamento e incorporação de novos produtos à esfera da produção, como minério, carvão mineral e madeiras. Especificamente as ferrovias, em linhas gerais, asseguraram maior exatidão no cumprimento dos horários, encurtaram distâncias e diminuíram custos dos fretes. Em relação aos aspectos socioeconômicos imanentes a estas transformações, a Segunda Revolução dos Transportes contribuiu também para a consolidação de face da divisão internacional do trabalho, ao colocar de um lado os que possuiam a tecnologia ferroviária (Inglaterra, França, EUA e Alemanha) e, do outro, os compradores de

\footnotetext{
${ }^{3}$ MARX, Karl. O capital, Livro III, Volume I. São Paulo: Nova Cultural, 1988.

${ }^{4}$ A Primeira Revolução dos Transportes se iniciou com a navegação marítima e se estendeu até a ampliação dos canais e macadamização das rodovias e foi essencial para a realização da Primeira Revolução Industrial.
} 
Transportes, modernização e formação regional - subsídios à história da era ferroviária ....

quase todos os materiais permanentes e rodantes necessários para montagem das ferrovias ${ }^{5}$.

O desenho radial das ferrovias é revelador do papel que desempenham. Em resumo, fora da Europa, as ferrovias se dividem em três categorias: vias de penetração, que seguem da costa ao interior, redes interligadas às vias de penetração por ramais transversais e vias continentais que atravessam um continente e proporcionam desenvolvimento econômico ${ }^{6}$. As ferrovias do Brasil se enquadram nos dois primeiros tipos e tiveram as seguintes características: i. rápida expansão a partir da consolidação das economias exportadoras regionais; ii. redução dos custos de escoamento da produção agrícola, tendo em vista basicamente o atendimento a mercados externos, com a consolidação de sistema dotado de certa capilaridade, baseado em ramais alimentadores do tronco principal. Este atributo do sistema ferroviário brasileiro permitiu carregamentos de matérias-primas e alimentos para exportação, o transporte de cargas fracionadas e encomendas e a distribuição de manufaturados (majoritariamente importados) nas áreas de influência dos portos regionais, como subsidiárias da função de exportação ${ }^{7}$.

O ponto inicial da era ferroviária brasileira está associado ao Decreto $\mathrm{n}^{\circ} 641$, de 1852 , que autorizava a companhia que construísse a fazer a ligação total ou parcial das províncias do Rio de Janeiro, São Paulo e Minas Gerais, dava garantia de 5\% de juros sobre o capital investido, além de obtenção não onerosa de terras e isenção de direitos de importação de carvão mineral e equipamentos ferroviários ${ }^{8}$. A companhia beneficiária foi incapaz de levantar capital para a efetivação do empreendimento, mas o Decreto cumpriu bem sua função. Em abril de 1854, a

\footnotetext{
${ }^{5}$ SILVEIRA, Márcio Rogério da. A importância geoeconômica das estradas de ferro no Brasil. São Paulo: Faculdade de Ciências e Tecnologia - UNESP de Presidente Prudente, Tese de Doutorado, 2003. p.66.

${ }^{6}$ MAURO, Frédéric. História econômica mundial. Rio de Janeiro: Zahar Editores, 1976. p. 202.

${ }^{7}$ BARAT, Josef. Logística, transportes e desenvolvimento. São Paulo: CLA Editora, 2007. p. 23.

${ }^{8}$ ACCIOLI, Rodrigo Girdwood. Os mecanismos de financiamento das ferrovias brasileiras. Rio de Janeiro: Programa de Engenharia de Transportes, Universidade Federal do Rio de Janeiro, 2007. Dissertação de Mestrado.
} 
locomotiva Baroneza ${ }^{9}$, da Imperial Companhia de Navegação a Vapor e Estrada de Petrópolis, comandada por Irineu Evangelista de Sousa, inaugurou os primeiros $14,5 \mathrm{~km}$ da malha ferroviária brasileira.

Apesar de ter promovido o assentamento dos primeiros trilhos no Brasil, o Decreto $\mathrm{n}^{\circ} 641$ não garantiu dinamicidade à indústria dos transportes que, até 1872, expandiu-se por somente $932 \mathrm{~km}$. Marco legal também determinante para a era ferroviária foi o Decreto $\mathrm{n}^{\circ} 2450$, de 1873 , por meio do qual eram concedidas subvenções quilométricas ou garantias de juros ${ }^{10}$. Ao final da década de 1870, os trilhos atingiam o montante de $2.653,3 \mathrm{~km}$.

\footnotetext{
${ }^{9}$ No livro de Hélio S. RODRIGUES, sobre a memória das ferrovias do Rio de Janeiro, há breve relato da construção da Estrada de Ferro Mauá (A formação das estradas de ferro no Rio de Janeiro. Um resgate de sua memória. Rio de Janeiro: Editora Memória do Trem, 2004. p. 16-19), com fotografias da pioneira locomotiva Baroneza, trechos e estações da estrada. Para detalhes do envolvimento de Mauá nos negócios ferroviários na América do Sul, ver a biografia de autoria de Jorge CALDEIRA (Mauá: o empresário do Império. São Paulo: Companhia das Letras, 1995).

${ }^{10} \mathrm{Tal}$ Decreto instituiu cinco importantes alterações em relação ao Decreto $n^{\circ}$ 641: i. elevou o valor dos juros garantidos de $5 \%$ para $7 \%$; ii. estabeleceu o tempo máximo de 30 anos em que o capital investido teria tal privilégio; iii. requereu comprovações estatísticas de que o empreendimento apresentaria renda líquida superior a $4 \%$ ao ano; iv. estabeleceu limite máximo sobre o capital garantido e v. afiançou as garantias de juros e subvenções cedidas por concessões provinciais. A Lei $n^{\circ} 5561$, de 28/02/1874 e o Decreto n ${ }^{\circ} 6995$ de 10/08/1878 não estabeleceram mudanças importantes na política ferroviária. Apenas confirmariam a tendência já expressa de apropriação de recursos públicos por capitais privados no processo de expansão ferroviária (ACCIOLI, Rodrigo Girdwood. Os mecanismos de financiamento das ferrovias brasileiras. Rio de Janeiro: Programa de Engenharia de Transportes, Universidade Federal do Rio de Janeiro, 2007. Dissertação de Mestrado).
} 
Transportes, modernização e formação regional - subsídios à história da era ferroviária ....

Tabela 1 - Malha ferroviária brasileira, 1854-1970

\begin{tabular}{rrrrrrrrrr}
\hline \hline Ano & $\begin{array}{c}\text { Extensão } \\
\text { em tráfego } \\
\mathbf{( K m )}\end{array}$ & Acréscimo & Ano & $\begin{array}{c}\text { Extensão em } \\
\text { tráfego } \mathbf{( K m})\end{array}$ & Acréscimo & Ano & $\begin{array}{c}\text { Extensão } \\
\text { em tráfego } \\
\mathbf{( K m )}\end{array}$ & $\begin{array}{c}\text { Extensão } \\
\text { em tráfego } \\
\text { (Km) }\end{array}$ \\
\hline \hline 1854 & $\mathbf{1 4 , 5}$ & 0,0 & 1900 & $15.316,4$ & $5.343,3$ & 1930 & $32.478,0$ & 510,6 \\
\hline 1860 & $\mathbf{2 2 2 , 7}$ & 208,2 & 1910 & $21.325,6$ & $6.009,2$ & 1940 & $34.251,7$ & $1.773,7$ \\
\hline 1864 & $\mathbf{4 1 1 , 0}$ & 188,3 & 1912 & $23.491,0$ & $2.165,4$ & 1950 & $36.681,0$ & $2.429,3$ \\
\hline 1869 & 713,0 & 302,0 & 1920 & $28.534,9$ & $5.043,9$ & 1955 & $37.092,0$ & 411,0 \\
\hline 1870 & 744,1 & 31,1 & 1925 & $30.731,5$ & $2.196,6$ & 1957 & $37.422,0$ & 330,0 \\
\hline 1872 & 932,0 & 187,9 & 1926 & $31.332,8$ & 601,3 & 1958 & $37.987,0$ & 565,0 \\
\hline 1874 & $1.357,0$ & 425,0 & 1927 & $31.549,0$ & 216,3 & 1959 & $37.721,0$ & $-266,0$ \\
\hline 1880 & $3.397,9$ & $2.040,9$ & 1928 & $31.851,2$ & 302,2 & 1960 & $38.339,0$ & 618,0 \\
\hline 1890 & $9.973,1$ & $6.575,2$ & 1929 & $31.967,4$ & 116,2 & 1970 & $31.878,0$ & $-6461,0$ \\
\hline \hline
\end{tabular}

Fontes: Anuário Estatístico do Brasil, vários anos (BRASIL. Rio de Janeiro: Tipografia de Estatística. 1908/1912; Tipografia do Departamento de Estatística e Publicidade, 1936 - 1937 - 1939/40; Serviço Gráfico do IBGE, 1946/52 - 1960/61 - 1970)

Os dados compilados na Tabela 1 permitem acompanhar o avanço gradativo no ritmo de construção das estradas de ferro. Enquanto na década de 1860 foram assentados $521,4 \mathrm{~km}$ de trilhos, na década de 1870, foram construídos $2.653,3 \mathrm{~km}$. O período compreendido entre 1880 e 1920 marcou o auge da era ferroviária brasileira. A média de avanço dos trilhos de $125 \mathrm{~km} /$ ano entre 1854-1880 atingiria a surpreendente média de 613 $\mathrm{km}$ anuais nas quatro décadas seguintes. Dos 3.397,9 km de trilhos assentados em 1880, saltou-se para 28.534,9 em 1920. Nas três décadas seguintes, reduziu-se substantivamente o ritmo de expansão ferroviária, média anual de $262,7 \mathrm{~km}$, com a malha ferroviária nacional atingindo $36.681 \mathrm{~km}$ em 1950 . Se na década de 1950 observou-se persistente crescimento, 165,8 $\mathrm{km} /$ ano, a década de 1960 foi marcada por significativa desativação, redução próxima a $20 \%$.

A malha ferroviária, eixo dos transportes sob o primado de modelo primário-exportador, tendeu a privilegiar as regiões mais estreitamente vinculadas a tal dinâmica. A alta densidade da malha ferroviária no Centro-Sul pode ser percebida pelos dados retirados do Anuário Estatístico de 1908-1912: dos 17.401,640 $\mathrm{km}$ da rede federal abertos ao tráfego, $74 \%$ pertenciam a 
São Paulo, Minas Gerais, Rio de Janeiro e Espírito Santo, e dos $6.089,7 \mathrm{~km}$ das redes estaduais, $88 \%$ estavam localizados nestes mesmos estados.

Se, por um lado, as ferrovias refletiram inserção subordinada da estrutura econômica nacional à dinâmica capitalista mundial, garantindo contato direto das zonas produtoras de bens primários com o litoral, adensando-se onde o setor exportador apresentava maior vigor, por outro, estreitaram, ainda que parcialmente, os laços das economias regionais. Respeitar a forma de inserção da economia brasileira na divisão internacional do trabalho não significa olvidar as características histórico-estruturais e políticas de cada região do Brasil e, por decorrência, as especificidades da modernização dos transportes em cada realidade regional ${ }^{11}$.

\section{Miopia política e perda de substância: a implantação do ferroviarismo em Minas}

A política imperial de modernização dos transportes impactou, em escala variável, sobre a estrutura produtiva das províncias. No caso específico de Minas Gerais, a expansão ferroviária, ainda que pródiga em termos de extensão da malha construída, não resultou na dinamização da economia regional. O ritmo, a forma e o traçado com que os trilhos quebraram o isolamento geográfico dos mercados das regiões mineiras reduziram os custos do transporte e normatizaram o fluxo de pessoas, bens e informações, não se desdobraram na conformação de sistema de transportes moderno funcional a políticas de desenvolvimento regional, além de representarem elevado ônus para as finanças provinciais, depois estaduais.

No período imperial, os três planos viários elaborados para Minas Gerais objetivaram modernizar a infraestrutura de transportes. Os planos de 1835, elaborado por Bernardo Pereira Vasconcelos, de 1864, pelo engenheiro Henrique Gerber, e o de 1871, pelo engenheiro Modesto Faria Bello, destacam-se por dupla preocupação: ligar a economia mineira a mercados externos, especialmente ao do Rio de Janeiro, e superar o problema

${ }_{11}^{11}$ NATAL, Jorge Luiz Alves. Transporte, ocupação do espaço e desenvolvimento capita-
lista no Brasil: história e perspectivas. Campinas: UNICAMP, 1991. Tese de Doutorado. 
Transportes, modernização e formação regional - subsídios à história da era ferroviária ....

da desarticulação interna. As políticas viárias convergiram para a combinação entre múltiplas modais, sem desconsiderar a modernização dos transportes tradicionais ${ }^{12}$.

Destarte, desde a Mensagem do vice-presidente Costa Pinto, em 1837, é possivel constatar a alta frequência com que a exploração de rios e canais foi estudada. Em 1843, por exemplo, foi proposto que no ponto inicial da navegação do São Francisco fosse levantada uma nova capital provincial. O engenheiro Heinrich W. F. Halfeld foi designado para explorar o Rio São Francisco e seus afluentes desde a cachoeira de Pirapora até o oceano Atlântico, por incumbência do Governo Imperial, pesquisa que realizou entre 1852 e 1854 e que resultou na publicação do Atlas e Relatório Concernente à Exploração do Rio São Francisco. No fim da década de 1840, os irmãos Ottoni empreendiam a navegação a vapor do Rio Mucury e a construção de estrada a ligá-lo a Minas Novas ${ }^{13}$. O maior entusiasta de projeto hidroviário parece ter sido, todavia, o presidente Joaquim Saldanha Marinho que, em 1867, coletou dados que revelaram potencial de $3.600 \mathrm{~km}$ de rios navegáveis em Minas ${ }^{14}$.

Embora as políticas voltadas para a navegação fluvial estejam presentes nos relatórios de presidentes de província, as estradas de terra e as pontes e, posteriormente, as ferrovias, foram priorizadas pela administração pública. Fato que pode ser depreendido do montante de recursos destinados para os transportes tradicionais e, depois, para a expansão ferroviária, nos orçamentos da província e dos municípios de Minas Gerais ${ }^{15}$. Contudo, no final do Império e início da República, as ferrovias assumiriam lugar destacado nas políticas de transportes dos governos mineiros, com substantiva transferência para as

${ }^{12}$ GODOY, Marcelo Magalhães e BARBOSA, Lidiany Silva. "Uma outra modernização: transportes em uma província não-exportadora - Minas Gerais, 1850-1870". Economia e Sociedade. vol.17, n.2, p. 159-186. 2008.

${ }^{13}$ ARAÚJO, Valdei Lopes. A Filadélfia de Theophilo Ottoni. Uma aventura cidadã. Belo Horizonte: Afato, 2003.

${ }^{14}$ PROVÍNCIA DE MINAS GERAIS. Mensagem de presidente de província. Anos de 1837, 1846, 1847, 1852 e 1867. Disponível em: <www.crt.edu.brazil/provincial/minas_gerais>. Acesso em: $10 \mathrm{dez} .2009$.

${ }^{15}$ Consideram-se transportes tradicionais as formas classificadas por José Alípio GOULART, em Meios e Instrumentos de Transportes no Interior do Brasil, mais especificamente aquelas descritas na parte dedicada aos transportes terrestres (Rio de Janeiro: MEC, Serviço de Documentação, Departamento de Imprensa Oficial, 1959. p. 119-253). 
municipalidades do dispêndio com a manutenção e ampliação da malha viária tradicional ${ }^{16}$.

As contradições da expansão ferroviária em Minas Gerais estariam consolidadas com o advento da República, com modelo de federalismo que quebrou as amarras institucionais da centralização imperial e facultou aos estados ampla autonomia no plano fiscal e na gestão das politicas de transportes. Agravou-se o caráter disfuncional da malha ferroviária mineira, moderna pela sua base tecnológica, mas inadequada para instrumentalizar correspondente modernização econômica.

A mudança da capital para Belo Horizonte, inaugurada oficialmente em 1897, a união da elite regional em torno do Partido Republicano Mineiro, consolidada em 1906, e a realização do Congresso Agrícola, Industrial e Comercial, em $1903^{17}$, foram reações tardias e incapazes de impedir a perda de substância econômica de Minas Gerais, a posição de atraso relativo em relação a São Paulo e ao Rio de Janeiro e, em processo de longo prazo, a inserção economicamente subordinada do estado na divisão inter-regional do trabalho que se conformaria após $1930^{18}$. Portanto, a primeira modernização dos transportes em Minas, entre 1870 e 1940, coincidiu com a transição de dinâmica economia mercantil escravista, no século XIX, para formação econômica regional em posição crescentemente periférica no quadro de mercado interno integrado em bases capitalistas. Com a segunda modernização dos transportes, a partir da década de

\footnotetext{
${ }^{16}$ BARBOSA, Lidiany Silva; GODOY, Marcelo Magalhães; MENDES, Philipe Sherrer. "Transportes e finanças públicas: contribuição para o estudo do lugar do dispêndio em infra-estrutura viária nos orçamentos provinciais e municipais de Minas Gerais, 1835-1889". In: GOULARTI FILHO, Alcides e QUEIROZ, Paulo R. Cimo. Transportes e formação regional: contribuição à história dos transportes no Brasil. Dourados: Editora UFGD, 2011.

${ }^{17}$ Este evento é marco do início da mobilização da elite mineira por projeto político que visava recolocar Minas Gerais em posição de proeminência econômica em âmbito nacional. O Congresso concretizado por Francisco Sales, então presidente do estado, e dirigido por João Pinheiro, foi interpretado como pioneiro do desenvolvimentismo em Minas, e com a participação de expressiva parcela da elite regional. No encontro, foram marcantes temas relativos à promoção do desenvolvimento de Minas, bem como a discussão acerca das melhores formas de intervenção na economia (FARIA, Maria Auxiliadora. A Política da Gleba: as classes conservadoras mineiras: discurso e prática na Primeira República. São Paulo: Universidade de São Paulo, 1992. Tese de Doutorado. DULCI, Otávio S. Política e recuperação econômica em Minas Gerais. Belo Horizonte: Editora da UFMG, 1999).

${ }^{18}$ DULCI, Otávio Soares. Política e recuperação econômica em Minas Gerais. Belo Horizonte: Editora da UFMG, 1999.
} 
1940 e com base no rodoviarismo, a economia regional mineira consolidou inserção subordinada no mercado nacional ${ }^{19}$. O Binômio Energia e Transporte e o Plano de Metas, ambos sob a direção de Juscelino Kubitschek, primeiro no plano estadual e depois no federal, impulsionariam vigorosamente a expansão da malha rodoviária mineira, não apenas avançando a integração das regiões do estado, mas, principalmente, ampliando a integração de Minas com o mercado interno nacional ${ }^{20}$.

\section{A ERA FERROVIÁRIA MINEIRA - Evolução das companhias em Minas Gerais (ver Mapa 1)}

\section{Estrada de Ferro Dom Pedro II (Estrada de Ferro Cen-} tral do Brasil) A Estrada de Ferro Central do Brasil foi a primeira ferrovia a penetrar o território mineiro, embora ainda não tivesse esse nome, com a inauguração das estações de Serraria e Chiador em 27 de junho de 1869. Essa ferrovia foi concedida com base na Lei $\mathrm{n}^{\circ} 641$, de 1852, e autorizada pelos Decretos Imperiais $n^{\circ} 1598$ e 1599, ambos de 1855, com a formação da Sociedade Anônima Companhia da Estrada de Ferro D. Pedro II. À Companhia foram concedidos privilégios de construção, uso e gozo da estrada de ferro por 90 anos, e garantia de juros de $5 \%$ sobre o capital investido. Seus trilhos seriam assentados a partir da capital do Império e, após a transposição da serra do Mar e antes de atingir o Rio Paraíba do Sul, bifurcariam-se em dois ramais: um se dirigiria à povoação de Cachoeira, o outro ao Porto Novo do Cunha, em Minas Gerais ${ }^{21}$.

Apesar de adentrar a provincia mineira somente em 1869, desde dezembro de 1856, a Pedro II já havia requerido, e a Assembleia Provincial de Minas concedido, garantia adicional de $2 \%$ de juros sobre o capital investido e licença para direcionar

\footnotetext{
${ }^{19}$ GODOY, Marcelo Magalhães. "Minas Gerais na república: atraso econômico, Estado e planejamento". Cadernos da Escola do Legislativo. Belo Horizonte, vol. 11, n. 16, 2009.

${ }^{20}$ DINIZ, Clélio Campolina. Estado e capital estrangeiro na industrialização mineira. Belo Horizonte: UFMG/PROED, 1981.

${ }^{21}$ PIMENTA, Demerval. Caminhos de Minas Gerais. Belo Horizonte: Imprensa Oficial, 1971. JACOB, Rodolpho. Minas Geraes no XX⿳0 seculo. Rio de Janeiro: Gomes, Irmão \& C, 1911.
} 
seus trilhos pelo interior da província ${ }^{22}$. Tais concessões se justificariam pela centralidade que a estrada assumiria, como se pode perceber por fala do presidente provincial João Crispiano, de 1864:

E se me é permittido aventar alguma idéa sobre materia que me é muito estranha, direi, que todo o systema de estradas deve partir da estrada de ferro de Pedro II e encaminhar-se pra três pontos, o valle do Rio Grande, - o Rio das Velhas, e o Rio Doce. A cada um destes troncos todas as mais estradas se devem prender como ramos de uma grande e magestosa arvore, que formará a rede secundaria dos caminhos provinciaes, municipaes e vicinaes ${ }^{23}$.

Assim, a linha do centro de Minas da Pedro II partia de Entre Rios e seguia para o interior de Minas. Passava pelas estações de Serraria e Paraibuna, inaugurada em 1874; atingia Juiz de Fora no ano de 1875; Barbacena, em 1880; chegava a Ouro Preto, em 1887; Belo Horizonte, em 1895; Corinto, onde sofria bipartição, em 1905; Pirapora, em 1910; Montes Claros, em 1926. Tremendal, ponto de entroncamento com a Estrada de Ferro Leste Brasileiro, é alcançado em 1950, quando a Companhia possuía $2.061,808 \mathrm{~km}$ de extensão ${ }^{24}$.

Rede Sul Mineira (Estrada de Ferro Sul de Minas) A Rede Mineira de Viação, criada a partir do Decreto $\mathrm{n}^{\circ} 9882$, de 1931, resultou da fusão de duas estradas tributárias da antiga Central do Brasil25: a Oeste de $\operatorname{Minas}^{26}$ e a Sul de Minas.

${ }^{22}$ PROVÍNCIA DE MINAS GERAIS. Mensagem de presidente de província. Ano de 1857. Disponível em: <www.crt.edu.brazil/provincial/minas_gerais>. Acesso em: 10 dez. 2009.

${ }^{23}$ PROVÍNCIA DE MINAS GERAIS. Mensagem de presidente de província. Ano de 1864: 17. Disponível em: <www.crt.edu.brazil/provincial/minas_gerais>. Acesso em: $10 \mathrm{dez}$. 2009.

${ }^{24}$ PIMENTA, Demerval. Caminhos de Minas Gerais. Belo Horizonte: Imprensa Oficial, 1971. JACOB, Rodolpho. Minas Geraes no XX⿳0 seculo. Rio de Janeiro: Gomes, Irmão \& C, 1911. PROVÍNCIA DE MINAS GERAIS. Mensagem de presidente de província. Ano de 1880. Disponível em: <www.crt.edu.brazil/provincial/minas_gerais>. Acesso em: 10 dez. 2009. ESTADO DE MINAS GERAIS. Mensagem de presidente de estado. Anos de 1889, 1907, 1910 e 1926. Disponível em: <www.crt.edu.brazil/provincial/minas_gerais>. Acesso em: 10 dez. 2009.

${ }^{25}$ Estrada de Ferro Central do Brasil é a denominação do período republicano para a Estrada de Ferro D. Pedro II.

${ }^{26}$ Estudo de Welber Luiz dos SANTOS. A Estrada de Ferro Oeste de Minas: São João delRei, 1877-1898. Mariana: PPGHIS-UFOP, 2009. Dissertação de Mestrado sobre a Oeste de Minas apresenta informações importantes, como a evolução da receita e a despesa da empresa, bem como a identificação de seus diretores e acionistas no período de 1877 a 1898 . 
Transportes, modernização e formação regional - subsídios à história da era ferroviária ....

Consubstanciou-se na mais extensa entre as companhias ferroviárias de Minas Gerais, com seus $3.500 \mathrm{~km}$, no ano de 1940. Os prolongamentos da Central do Brasil, a partir de Barra do Piraí, seguem o Rio Paraíba do Sul. Enquanto o ramal de Porto Novo acompanha o fluxo do rio e adentra o território mineiro, o de Cruzeiro sobe o rio até a estação do mesmo nome. É nas proximidades de Cruzeiro (SP) onde têm início os trilhos que adentram Minas Gerais.

Com base na Lei provincial $\mathrm{n}^{\circ} 2062$, de 1874 , foi concedido privilégio de 50 anos e garantia de juros sobre o capital máximo de Rs. 14.000:000\$000 ${ }^{27}$ à companhia que construísse uma estrada de ferro que buscasse a confluência dos rios Sapucaí e Verde. Adquirida em 1875, foi organizada a Companhia Estrada de Ferro Rio Verde. A empresa apenas iniciou o assentamento dos trilhos e, em 1880, transferiu seus privilégios à Companhia inglesa Minas and Rio Railway. Em 1884, os $147 \mathrm{~km}$ que compunham a estrada estavam construídos. Apesar dos saldos positivos desde sua inauguração, a estrada foi encampada em 1901 pela União por $£ 1.150 .600$ e imediatamente arrendada a um particular. Este primeiro contrato de arrendamento seria rescindido em 1909 e, junto à já encampada Muzambinho, seria arrendada à Estrada de Ferro do Vale do Sapucaíi ${ }^{28}$.

A Estrada de Ferro do Vale do Sapucaí, organizada originalmente em 1888, foi detentora do monopólio de 50 anos da linha que partia de Soledade, na Minas and Rio, e passava por Caxambú, Itajubá, Pouso Alegre e Sapucaíi ${ }^{29}$. Os trabalhos de construção iniciaram-se no ano de 1889; em 1890, a Companhia adquiriu mais duas concessões: da estação de Soledade e Baependi, e de Lavras a Santa Rita do Jacutinga. Em 1891, estavam franqueados os $108 \mathrm{~km}$ entre Caxambú e Itajubá. Em

\footnotetext{
${ }^{27}$ O capital máximo garantido seria elevado depois a Rs. 16.150:000\$000 pelo Governo Geral, que além de afiançar a garantia provincial, concedeu garantia adicional de $3 \%$ de juros sobre o capital primitivo e 7\% sobre o capital extra de Rs. 2.150:000\$000.

${ }^{28}$ PROVÍNCIA DE MINAS GERAIS. Mensagem de presidente de província. Anos de 1874 e 1875. Disponível em: <www.crt.edu.brazil/provincial/minas_gerais>. Acesso em: $10 \mathrm{dez}$. 2009. JACOB, op. cit.

${ }^{29} \mathrm{O}$ contrato estabelecia também garantia de juros de $7 \%$ sobre capital máximo de Rs. 6.000:000\$000, por 20 anos, e privilégio de zona de $30 \mathrm{Km}$. Em 01/12/1888, a Lei $\mathrm{n}^{\circ} 3648$ elevaria o capital garantido a Rs. 10.000:000\$000.
} 
1892, os sinais de debilidade financeira já eram visíveis e, no ano de 1893, foram paralisadas as obras ${ }^{30}$.

Segundo o presidente do estado Affonso Penna, a responsabilidade pelo insignificante desenvolvimento da malha, em 1893, decorria da política do Encilhamento e da especulação subsequente. Ao Governo coube assumir responsabilidade pelo não abandono das principais linhas em andamento e também da realização das imediatamente necessárias. Para tanto, foi expedida a Lei $\mathrm{n}^{\circ} 64$, em julho de 1893, que autorizava o Governo Estadual a conceder empréstimos às companhias. A Viação Sapucahy, auxiliada com Rs. 6.920:000\$000, distribuídos entre os anos de 1894 e 1898, foi a empresa que mais se beneficiou desses créditos extraordinários e totalizou $224 \mathrm{~km}$ de linhas franqueadas. Apesar das melhorias realizadas na linha, as dificuldades financeiras persistiram e a Companhia entrou em liquidação forçada em 1899. O governo administrou-a entre março e novembro do mesmo ano, quando reorganizada sob a denominação de Companhia de Viação Férrea Sapucaí, voltou à administração particular ${ }^{31}$.

As várias concessões que deram origem à malha da $\mathrm{Mu}-$ zambinho não têm origem única, mas resultaram de privilégios concedidos tanto pela União como pelo Estado de Minas Gerais. Deste modo, as concessões dos trechos de Três Corações à Fluvial e de Freitas à Campanha são federais ${ }^{32}$. O trecho Fluvial a Areados tem origem em concessões provinciais nos anos de 1888 e 1889, sem que fossem concedidos privilégios ${ }^{33}$. Incapaz de assentar seus trilhos, a companhia foi auxiliada pelo Governo Estadual, por meio da Lei $n^{\circ} 64$, entre os anos de 1894 e 1898, com Rs. 5.644:4120\$000. Endividada, suas concessões e privilégios foram considerados caducos e a empresa foi

\footnotetext{
${ }^{30}$ ESTADO DE MINAS GERAIS. Mensagem de presidente de estado. Anos de 1890 a 1894. Disponível em: <www.crt.edu.brazil/provincial/minas_gerais>. Acesso em: 10 dez. 2009.

${ }^{31}$ ESTADO DE MINAS GERAIS. Mensagem de presidente de estado. Anos de 1894, 1895, 1896, 1897 e 1898. Disponível em: <www.crt.edu.brazil/provincial/minas_gerais>. Acesso em: 10 dez. 2009.

${ }^{32}$ A garantia de juros de $4 \%$ durante o tempo de construção e $5 \%$ depois de aberto o tráfego, sobre o capital de Rs. 2.509:500\$000, foi concedida somente ao ramal de Campanha.

${ }^{33}$ Somente em 1893 , adendos nos contratos estabeleceram a garantia de juros de $6 \%$, à razão de Rs. 25:000\$000 por quilômetro. JACOB, op. cit.
} 
encampada pelo Governo Estadual, por Rs. 12.000:000\$000, no ano de 1907. Em 1908, foi transferida pelo mesmo preço à União e, no ano seguinte, seus $248 \mathrm{~km}$ de trilhos foram arrendados à Sapucaí ${ }^{34}$.

Formada em 1910, quando foram arrendadas à Sapucaí, a Minas and Rio e a Muzambinho, a Rede Sul Mineira passou a deter a mais extensa malha do Sul de Minas. Apesar de sua importância, a incapacidade da empresa em realizar seus serviços levou à rescisão do contrato e encampamento pelo Governo Federal em 1920. Em 1921, novo contrato foi celebrado entre a União e o Governo Estadual. Este assumiu a responsabilidade pela administração e obrigação de despender Rs. 15.000:000\$000 em melhoramentos. Apesar de caber ao tesouro estadual metade da receita líquida gerada no tráfego, o contrato implicou pesado fardo aos cofres - somente entre 19231929, foram gastos Rs. 72.248:000\$000 no aparelhamento e expansão da estrada ${ }^{35}$. Em 1953, o Governo Estadual devolveu-a a União e livrou-se dos elevados custos que a empresa representava ${ }^{36}$. Suas mais significativas construções foram: o trecho entre Soledade e Encruzilhada, que permitiu ligação com a Central do Brasil, e a construção do trecho Três Corações a Lavras. Foi ampliada também pela política de encampação levada à frente pelo poder público, que tomaria o controle, na década de 1920, de $41 \mathrm{~km}$ da Estrada de Ferro Machadense, de $20 \mathrm{~km}$ da Trespontana e de $31 \mathrm{~km}$ da São Gonçalo do Sapucaí.

Estrada de Ferro Oeste de Minas A Rede Mineira de Viação foi estabelecida a partir da fusão da Rede Sul Mineira e da Estrada de Ferro Oeste de Minas, cuja organização remonta à concessão provincial de 1873, que estabeleceu subvenção de Rs. 9:000\$000 por quilômetro de estrada construída, monopólio de 50 anos e privilégio de zona de $30 \mathrm{~km}$ à empresa ferroviária que ligasse São João Del Rei a um ponto da D. Pedro II.

\footnotetext{
${ }^{34}$ ESTADO DE MINAS GERAIS. Mensagem de presidente de estado. Anos de 1898 e 1908. Disponível em: <www.crt.edu.brazil/provincial/minas_gerais>. Acesso em: 10 dez. 2009.

${ }^{35}$ ESTADO DE MINAS GERAIS. Mensagem de presidente de estado. Anos de 1910, 1921 e 1929. Disponível em: <www.crt.edu.brazil/provincial/minas_gerais>. Acesso em: $10 \mathrm{dez}$. 2009.

${ }^{36}$ DINIZ, Clélio Campolina. Capitalismo, recursos naturais e espaço. Tese de Professor Titular do Departamento de Ciências Econômicas. Faculdade de Ciências Econômicas, Universidade de Minas Gerais. Belo Horizonte: 1985.
} 
A Companhia, levantada com capital nacional, apresentou constantes déficits desde sua inauguração. Em 1900, entrou em liquidação forçada e, três anos mais tarde, foi adquirida em leilão pela União ${ }^{37}$.

Em 1881 foi inaugurado o primeiro trecho da Oeste de Minas, de $99 \mathrm{~km}$. No ano de 1885, por meio de nova concessão, os trilhos atingiram Oliveira e foi construído o ramal de Aureliano Mourão ao Rio Grande. Tal concessão tinha validade de 70 anos, garantia de juros de $7 \%$ sobre o capital máximo de Rs. 4.000:000\$000, pelo prazo de 30 anos, e privilégio de zona de 20 km. Em 1887 foi inaugurado o trecho entre São João Del Rei e Bom Sucesso e, em 1889, a estação de Oliveira e o trecho de Aureliano Mourão a Ribeirão Vermelho.

Em 1894, a linha tronco, de bitola 0,76m, estendia-se por $600 \mathrm{~km}$ e atingia as margens do Rio Paraopeba. Ficaria aí estancada e apenas seriam construídos ramais: i. Itapecerica, em 1891; ii. Pitangui, 1907; ii. Cláudio, 1912. O ramal de Ribeirão Vermelho, de $15 \mathrm{~km}$ e com bitola mista, foi construído nos anos de 1895 e 1896, a ligação entre Aureliano Brandão à Formiga foi construída entre os anos de 1896 e $1905^{38}$ e a de Lavras a Barra Mansa entre os anos de 1895 e 1915. A bitola de $1 \mathrm{~m}$ foi utilizada entre Garças à capital e de Formiga a Lavras. O porto de Angra dos Reis foi atingido no ano de 1928, a estação de Catalão, na outra ponta, foi inaugurada somente em $1942^{39}$, após a Oeste de Minas incorporar, em 1920, $356 \mathrm{~km}$ da Estrada de Ferro Goiás, de Formiga a Patrocínio, e concluir o restante do trajeto $^{40}$.

A participação da Estrada de Ferro Goiás no território de Minas se deve ao Decreto $\mathrm{n}^{\circ} 5349$, de 1904 , que concedia a construção da linha Araguari a Catalão, e do Decreto n 6438, de 1906, que determinava seu ponto inicial em Formiga e

${ }^{37}$ PROVÍNCIA DE MINAS GERAIS. Mensagem de presidente de província. Anos de 1875 e 1879. Disponível em: <www.crt.edu.brazil/provincial/minas_gerais>. Acesso em: $10 \mathrm{dez}$. 2009. ESTADO DE MINAS GERAIS. Mensagem de presidente de estado. Ano de 1903. Disponível em: <www.crt.edu.brazil/provincial/minas_gerais.. Acesso em: 10 dez. 2009.

${ }^{38}$ JACOB, op. cit.

${ }^{39}$ PIMENTA, op. cit.

${ }^{40}$ ESTADO DE MINAS GERAIS. Mensagem de presidente de estado. Anos de 1896, 1915 e 1920. Disponível em: <www.crt.edu.brazil/provincial/minas_gerais>. Acesso em: $10 \mathrm{dez}$. 2009. 
final em Catalão, além de conceder um ramal para Uberaba ${ }^{41}$. Os $53 \mathrm{~km}$ de Araguari a Catalão foram inaugurados até 1910, enquanto os $355 \mathrm{~km}$ de Formiga a Patrocínio, em 1918. Por não cumprir os acordos dos contratos de construção, o Governo Federal expediu o Decreto ${ }^{\circ} 13963$, em 1920, e assumiu a administração da linha de Araguary a Catalão,enquanto o trecho Formiga a Patrocínio foi anexado à Oeste de Minas. Em 1931, outros $156 \mathrm{~km}$ da Companhia Paracatu foram fundidos à Oeste de Minas. Neste mesmo ano, os $2.123 \mathrm{~km}$ da Oeste de Minas seriam encampados pelo Governo Estadual e, junto à Estrada Sul de Minas, conformariam a Rede Mineira de Viação ${ }^{42}$.

No que se refere à construção de trilhos pela Rede Mineira de Viação, ainda cabe ressaltar a finalização do trecho Patrocínio e Catalão, em 1942. O mais importante a se reter, todavia, é o pesado ônus que ela trouxe ao tesouro estadual, não somente pelos constantes déficits da Oeste de Minas, como pelos reaparelhamentos realizados na Rede Sul Mineira ${ }^{43}$.

Estrada de Ferro Mogiana A Companhia Mogiana, cujo grosso da malha situava-se em território paulista, apresentou prolongamentos em Minas. Além da atuação no Triângulo Mineiro, deteve três ramais de comunicação entre as malhas mineira e paulista: Poços de Caldas, Guaxupé e Itapira. Embora os trilhos da Mogiana não tenham ultrapassado $300 \mathrm{~km}$ em Minas, o arrendamento de parte da Rede Sul Mineira, na década de 1920, elevou sua importância na economia dos transportes do Sul de Minas, principalmente do café. Arrendadas as linhas que outrora pertenceram à Muzambinho, a malha da Mogiana em Minas atingiu $657,8 \mathrm{~km}^{44}$.

Estrada de Ferro Bahia a Minas A Estrada de Ferro Bahia a Minas apresentava, em 1930, a extensão de $512 \mathrm{~km}$, sendo $370 \mathrm{~km}$ em território mineiro, ligando Caravelas a Aymorés.

\footnotetext{
${ }^{41}$ JACOB, op. cit.

${ }^{42}$ ESTADO DE MINAS GERAIS. Mensagem de presidente de estado. Ano de 1935. Disponível em: <www.crt.edu.brazil/provincial/minas_gerais $\geq$. Acesso em: $10 \mathrm{dez} .2009$.

${ }^{43}$ ESTADO DE MINAS GERAIS. Mensagem de presidente de estado. Anos de 1935 a 1938 e 1947. Disponível em: <www.crt.edu.brazil/provincial/minas_gerais $\geq$. Acesso em: $10 \mathrm{dez}$. 2009. ESTADO DE MINAS GERAIS. Mensagem de presidente de estado. Belo Horizonte: Imprensa Official do Estado, 1943.

${ }^{44}$ ESTADO DE MINAS GERAIS. Mensagem de presidente de estado. Anos de 1921 e 1929. Disponível em: <www.crt.edu.brazil/provincial/minas_gerais>. Acesso em: 10 dez. 2009.
} 
Concretização da vontade de Theophilo Ottoni, seu objetivo consistia em abrir espaço para a colonização e desenvolvimento do nordeste mineiro: deviam-se assentar trilhos e obter saída para o mar. Concedida no ano de 1880 , com subvenção de Rs. 9:000\$000 por quilômetro, os trabalhos de construção do trecho mineiro foram lentos: iniciaram em 1883, atingiram Ladainha em 1919 e Araçuaí somente em 1942. Sua trajetória financeira também não foi marcada por prosperidade. Em 1895, o Governo Estadual adquiriu Rs. 5.000:000\$000 em títulos da divida da Companhia, emprestou Rs. 4.433:672\$108 pela Lei $\mathrm{n}^{\circ} 64$ e, em 1897, quando a divida da empresa montava a Rs. 20.029:616\$401, foi encampado o trecho mineiro. Esteve sob administração estadual até o ano de 1904, entre 1904-1911, sob administração privada, quando, então, foi encampada pelo Governo Federal. Entre 1912-1936, apesar de incorporada à Rede Bahiana de Viação Férrea, o trecho mineiro foi administrado pela arrendatária francesa Compagnie des Chemins de Fer Fédéraux d'Est Bresilien ${ }^{45}$.

Estrada de Ferro Leopoldina As estradas de ferro Leopoldina e Vitória a Minas estavam umbilicalmente relacionadas à realização de transporte especializado voltado para a exportação internacional. É complexa a história da Leopoldina, assim como a do ferroviarismo na Zona da Mata. Para além da ausência de planejamento e da elaboração de contratos confusos, é repleta de disputas políticas ${ }^{46}$. Atacada pela febre ferroviária entre 1874 e 1887, a região foi coberta por $750 \mathrm{~km}$ de linhas férreas - aproximadamente $50 \%$ da malha mineira no último $a^{47}$. A expansão ferroviária na Zona da Mata caracterizou-se pela desorganização e competição entre companhias.

\footnotetext{
${ }^{45}$ PROVÍNCIA DE MINAS GERAIS. Mensagem de presidente de província. Ano de 1883. Disponível em: <www.crt.edu.brazil/provincial/minas_gerais>. Acesso em: $10 \mathrm{dez} .2009$. ESTADO DE MINAS GERAIS. Mensagem de presidente de estado. Anos de 1895 a 1900, 1904, 1911, 1912, 1919, 1935 e 1937. Disponível em: <www.crt.edu.brazil/provincial/minas_gerais $>$. Acesso em: 10 dez. 2009. ESTADO DE MINAS GERAIS. Mensagem de presidente de estado. Belo Horizonte: Imprensa Official do Estado, 1935 - 1937.

${ }^{46}$ BLASENHEIN, Peter L. "As ferrovias de Minas Gerais no século dezenove". Em: Locus Revista de História, 2(2): 81-110. Juiz de Fora. Julho/Dezembro. 1996.

${ }^{47}$ PROVÍNCIA DE MINAS GERAIS. Mensagem de presidente de província. Anos de 1874, 1887 e 1888. Disponível em: <www.crt.edu.brazil/provincial/minas_gerais>. Acesso em: 10 dez. 2009.
} 
Transportes, modernização e formação regional - subsídios à história da era ferroviária ....

Desde a década de 1870 , quando 11 das 25 concessões outorgadas em Minas foram destinadas a Zona da Mata, é possivel acompanhar as disputas travadas na Assembleia Legislativa entre as Estradas de Ferro Leopoldina, Rio Doce, Alto Muriaé, Pirapetinga e União Mineira. Quem saiu vitoriosa foi a Leopoldina, que em 1890, já havia absorvido todas as demais concorrentes, exceto a Estrada de Ferro Juiz de Fora a Piau, cujos $58 \mathrm{~km}$ seriam incorporados em $1915^{48}$. Nessa direção, muito ilustrativo é o lugar ocupado pela Leopoldina na classificação das formas que assumem em plantas os traçados ferroviários, proposto pelo engenheiro Moacir M. F. Silva. A companhia é classificada como exemplo de rede irregular, quando as linhas sugerem não ter obedecido a princípio diretor algum:

A E. F. Leopoldina é o conjunto de vias férreas mais complicado que existe no Brasil, não só quanto a sua distribuição, como no que se relaciona com a intrincada história de cada uma de suas linhas férreas que entram na composição da rede ${ }^{49}$.

Portanto, o suposto sucesso da Leopoldina, cujas exportações de café garantiam constantes superávits e cuja extensão ultrapassava o território mineiro e atingia o Rio de Janeiro e o Espírito Santo, tende a esconder sua desorganização administrativa. Esta parece ser a causa de suas duas liquidações na década de 1890. Em 1898, reorganizou-se pelo capital inglês, enquanto Leopoldina Railway Company Limited e assim se manteve até o final da era ferroviária mineira, quando seus trilhos já atingiam $1.151,5 \mathrm{~km}$ e alcançavam Manhuaçu e Caratinga ${ }^{50}$.

Estrada de Ferro Vitória a Minas Já a Estrada de Ferro Vitória a Minas originou-se de projeto audacioso, datado de 1890, mas o empreendimento não se desdobraria em iniciativas até 1902, quando, por meio de alterações propostas por concessão estadual, seria organizada a Companhia Estrada de Ferro Vitória a Minas. Tais mudanças estabeleciam Diamantina

${ }^{48}$ ESTADO DE MINAS GERAIS. Mensagem de presidente de estado. Anos de 1890 a 1900 e 1915. Disponível em: <www.crt.edu.brazil/provincial/minas_gerais>. Acesso em: $10 \mathrm{dez}$. 2009.

${ }^{49}$ SILVA, Moacir M. F. "Geografia dos Transportes no Brasil”. Revista Brasileira de Geografia. v. 2, n. 3.1940. p. 417.

${ }^{50}$ ESTADO DE MINAS GERAIS. Mensagem de presidente de estado. Anos de 1890 a 1900 e 1930. Disponível em: <www.crt.edu.brazil/provincial/minas_gerais>. Acesso em: $10 \mathrm{dez}$. 2009. 
como ponto final da linha férrea e garantia de juros de $6 \%$ sobre o capital máximo de Rs. 30:000\$000 por $\mathrm{km}^{51}$. Os trabalhos foram iniciados no porto de Vitória, em 1903, e, no ano de 1907, atingiram Minas Gerais. Quando os trilhos da empresa se encontravam em Derrubadinha e preparavam-se para tomar a direção do Rio Suaçuí Grande, outras alterações no trajeto e novo objetivo foram impostos à ferrovia, que deveria chegar até as jazidas de minério de ferro de Itabira. As controvérsias decorrentes dessas alterações - em grande parte por pressão de capitalistas britânicos - acabaram por atrasar os prolongamentos dos trilhos. Assim, Cachoeira Escura só foi atingida em 1915, Desembargador Drumond em 1932 e Itabira em 1942, quando a estrada já havia sido incorporada pela Companhia Vale do Rio Doce ${ }^{52}$.

Principais características da era ferroviária mineira Minas Gerais ao fim da era ferroviária detinha a maior malha do país ${ }^{53}$. Os $8.176 \mathrm{~km}$ de trilhos, aproximadamente $25 \%$ da malha férrea brasileira, assentavam-se sobre uma área de aproximadamente $574.855 \mathrm{~km}^{2}$ e eram quase integralmente de posse do Governo Federal e arrendadas ao Governo Estadual ${ }^{54}$.

\footnotetext{
${ }^{51}$ A Companhia conseguiu integralizar montante de capital da ordem de 47 milhões de francos, lançados nas bolsas de Paris, Bruxelas e Amsterdam. PIMENTA, Demerval. Caminhos de Minas Gerais. Belo Horizonte: Imprensa Oficial, 1971.

${ }^{52}$ PIMENTA, op. cit.

${ }^{53}$ No processo de privatização das ferrovias do Brasil, no final do século $X X$, mais uma vez ficaram evidentes as contradições do ferroviarismo mineiro. Neste momento, a única ferrovia do estado era a Vitória-Minas (EFVM), não obstante Minas Gerais tenha possuído malha tão extensa no início do século XX. Dito em outros termos, quase todo o complexo ferroviário mineiro já estava desativado antes do final da primeira metade da década de 1990. Portanto, persiste uma única ferrovia mineira, a Estrada de Ferro Vitória-Minas, que faz a ligação entre o porto de Tubarão (Vitória-ES) e as jazidas da Companhia Vale do Rio Doce e a Belo Horizonte. Nesta ocasião, em virtude de seu volume de tráfego, sua moderna constituição física e operacional, foi definida como a mais importante ferrovia brasileira (MARQUES, Sérgio de Azevedo. "Privatização do Sistema Ferroviário Brasileiro". Texto para Discussão $\mathbf{N}^{\circ}$ 434. Brasília: IPEA, 1996: 9). A sobrevivência exclusiva da Vitória-Minas representa, no longo prazo, a demonstração do caráter disfuncional da primeira modernização dos transportes para a economia de Minas Gerais. O primado de modelo econômico a reafirmar a condição periférica do país, bem como a incipiência de iniciativas economicamente viáveis de integração do mercado interno, explicam a descontinuidade entre as eras ferroviária e rodoviária brasileiras. Em Minas sobrevive ferrovia que integra zonas de extrativismo mineral com porto marítimo, portanto no quadro de economia primário-exportadora.

${ }^{54}$ ESTADO DE MINAS GERAIS. Mensagem de presidente de estado. Belo Horizonte: Imprensa Official do Estado, 1953.
} 
Transportes, modernização e formação regional - subsídios à história da era ferroviária ....

Nascida sob a marca do sentido radial (litoral/portos interior/produção agrícola e mineral), a malha ferroviária da região foi incapaz de articular as várias sub-regiões que compunham a economia mineira. Construída a partir do eixo principal assumido pela Central do Brasil, as ferrovias de Minas Gerais se, por algum momento, buscaram autonomia em relação ao monopólio exercido pelo porto do Rio de Janeiro, o fizeram a fim de se ligarem a portos de exportação alternativos, como Vitória, Angra dos Reis e Santos. Até mesmo a Oeste de Minas que, em certo momento, parece comprometida com a busca pela integração do mercado interno do estado, voltou-se para a ligação com um porto de exportação.

A ausência de planejamento, compreendido em acepção larga, no assentamento dos trilhos, é marca da malha ferroviária mineira. Como se pode depreender da desarmonia entre essa infraestrutura moderna e as especificidades econômicas e naturais do espaço regional, da variação e incompatibilidade das bitolas, do predomínio de traçado irracional, na administração pouco eficiente e, sobretudo, na forma como as classes dirigentes da província, depois do Estado, atuaram na elaboração das políticas de transportes.

Outrossim, é importante destacar vozes dissonantes no âmbito da Assembleia Legislativa da Província de Minas Gerais, instituição responsável por grande parte das politicas para o setor de transportes no período imperial ${ }^{55}$. Três exemplos que abordam questões centrais na política ferroviária ensejaram amplo debate quando dos primórdios do ferroviarismo: a política de concessões, a necessidade de plano geral que guiasse a expansão dos trilhos e os impactos financeiros da concessão de privilégios nas contas públicas. O bacharel José Pereira dos Santos $^{56}$ é o primeiro dos exemplos. Ele criticou a forma como se realizavam as concessões para empresas não organizadas, que a seu ver deveriam ser evitadas, já que muitos pedidos visavam

\footnotetext{
${ }^{55}$ BARBOSA, Lidiany Silva. Tropas e ferrovias em uma província não-exportadora: Estado, elites regionais e as contradições da política de transportes no início da modernização Minas Gerais, 1835-1889. Tese de Doutorado. Rio de Janeiro: UFRJ/IFCS, 2011. p. 143-210.

${ }^{56}$ A identificação biográfica deste deputado foi obtida no estudo de Patrícia Falco GENOVEZ. O espelho da monarquia. Minas Gerais e a Coroa no Segundo Reinado. Rio de Janeiro: Universidade Federal Fluminense, 2003. Tese de Doutorado. p.359.
} 
comércio (venda do direito de construção de ferrovia autorizado pela concessão):

E o abuso criminoso de uns, e a má fé de outros, são elementos retardatários, senão deletérios para a organização de empresas úteis. Portanto; como bem intencionados legisladores devemos cercear os abuzos, evitando a prática ${ }^{57}$.

As críticas a concessões sem fundamentação encontram outro exemplo na fala do deputado Dr. Benedito Cordeiro dos Campos Valladares ${ }^{58}$, que, no ano de 1876, afirmou que inexistiam indústrias em Minas Gerais que pudessem sustentar as ferrovias e que as estradas de ferro que estavam sendo concedidas ou em vias de execução, durante muito tempo, só causariam efeitos negativos. Afirmou ainda que o verdadeiro princípio em estrada de ferro é que ellas sejão feitas para servir $a$ indústria ${ }^{59}$. Afirmou que a Assembleia deveria cuidar do tema com prudência. Valladares, em debate com colega, afirmou não ser um antiferrovias e sua visão da política de expansão ferroviária em Minas Gerais pode ser depreendida do excerto abaixo:

Eu disse que nossas circunstâncias são taes, que não ha outro remedio, se não decretarmos algumas estradas; mas que devemos proceder com tino e prudencia, decretando poucas estradas e as que nos parecerem mais viáveis e menos dispendiosas Srs. ${ }^{60}$.

O capitão Batista Pinto, morador da cidade de Cristina ${ }^{61}$, foi outro deputado que em vários momentos posicionou-se contra a forma como estava sendo pensada a política de transportes em Minas Gerais. Afirmou, inclusive, a necessidade de plano geral que guiasse a expansão dos trilhos e, ainda, destacou o exemplo paulista:

\footnotetext{
${ }^{57}$ Anais da Assembléia Provincial de Minas Gerais. Acervo do Arquivo Público Mineiro. 1872. p.36.

${ }^{58}$ Dados da biografia deste deputado podem ser encontrados em Peter BLASENHEIN “As ferrovias de Minas Gerais no século dezenove". Locus Revista de História, 2(2) p. 81-110. Juiz de Fora. Julho/Dezembro. 1996.

${ }^{59}$ Anais da Assembléia Provincial de Minas Gerais. Acervo do Arquivo Público Mineiro. $19^{a}$ Sessão de 19/05/1876. p. 167.

${ }^{60}$ Anais da Assembleia Provincial de Minas Gerais. Acervo do Arquivo Público Mineiro. $19^{a}$ Sessão de 19/05/1876. 168 p.

${ }^{61}$ Dados biográficos foram retirados dos Anais da Assembléia Provincial de Minas Gerais.

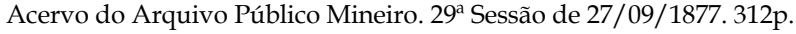


Transportes, modernização e formação regional - subsídios à história da era ferroviária ....

Batista Pinto: Mas a experiencia me tem feito comprehender que se é de toda conveniencia que cortemos a provincia com estradas de ferro, só o devemos decretar depois de um plano geral, para que uma estrada não venha fazer cuncurrencia a outra e prejudicarem-se mutuamente, como tem de acontecer, se continuarmos a decretar estradas de ferro a torto e a direito. Srs. nós devemos olhar para a provincia de S. Paulo que nos pode servir de modelo. O engrandecimento daquella provincia a que se deve? Á viação. Mas pergunto eu: a assembléa de S. Paulo tem concedido estradas da forma como temos concedido aqui? Não Srs. Sr. Valladares: Estudão primeiro todas as questões inherentes a uma estrada e que podem influir no seu desenvolvimento. Batista Pinto: A estradas são alli decretadas depois de estudo accurado e depois de orçamento bem detalhado. O Sr. Gaetano da Gama: As estradas alli são construídas principalmente pela inciativa individual. Batista Pinto: Depois de minuciosas indagações, depois de encarada a questão por todas as suas faces e depois de reconhecida a utilidade da estrada, depois que é ela decretada. Mas nós não procedemos assim; se pedirem uma estrada para a lua, a concederemos ${ }^{62}$.

Projeções negativas decorrentes dos impactos das ferrovias nas finanças provinciais foram recorrentes nos debates do Legislativo Provincial nos primórdios do ferroviarismo. Entre elas, uma merece destaque, a do deputado Antônio Luiz Maria Soares de Albergaria, que apresentou perspectiva importante. Questão amplamente debatida por alguns deputados foram as inúmeras consequências negativas para as finanças provinciais decorrentes da desordenada concessão de ferrovias subsidiadas pelo erário de Minas Gerais,como expõe, de forma exemplar, o deputado Albergaria. Deputado que em várias ocasiões buscou alertar sobre o estado aflitivo ${ }^{63}$ das finanças provinciais. Para tanto, afirmou seus predicados de conhecedor das contas públicas, uma vez que passou boa parte de sua vida em instituições fazendárias de Minas Gerais ${ }^{64}$. Em várias ocasiões, apresentou dados para mostrar a irracionalidade do financiamento público

\footnotetext{
${ }^{62}$ Anais da Assembleia Provincial de Minas Gerais. Acervo do Arquivo Público Mineiro.

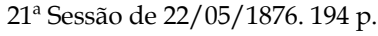

${ }^{63} \mathrm{O}$ sugestivo adjetivo aflitivo foi usado por Albergaria para definir o estado das contas de Minas no debate do Orçamento Provincial. Anais da Assembléia Legislativa de Minas Gerais. Acervo do Arquivo Público Mineiro. Discurso de 8/10/1883: 666/670.
}

${ }^{64}$ Anais da Assembleia Legislativa de Minas Gerais. Acervo do Arquivo Público Mineiro. $9^{a}$ Sessão ordinária, 14/08/1885. 
das ferrovias. De todos os recursos usados pelo deputado para demonstrar seu argumento, vale transcrição de trecho em que apresentou soma dos capitais retirados de compilação que realizou em todos os projetos de ferrovias que, no ano de 1883, estavam associados a pedidos de garantias de juros à Assembleia:

Albergaria: Para a estrada Leopoldina: 10.000:000\$; União Mineira: 3.000:000\$; Piau: 1.700:000\$; Jachutynga: 7.000:000\$; Sapucahy: 8.000:000\$; Filadélfia: 9.000:000\$; Campanha a Rio Verde: 800:000\$; Sabará a Itabira: 3.600:000\$. Temos, pois, nestes pedidos alguns dos quaes já satisfeitos o importante capital de 43.100:000\$ pheitos. N. Lages: Não é muito! Albergaria: Diz o nobre deputado que não é muito. Vou continuar. Se a esta avultada-mos, Sr. presidente, a constante na tabella $\mathrm{n}$. 13 , organizada pela directoria da fazenda provincial, dos creditos já votados para diversas estradas de ferro a importancia de 220.670:000\$, teremos o insignificante capital de 263.800 contos de reis, sobre o qual garantirá a provincia juros de $7 \%$ ! $\mathrm{E}$ notem os nobres deputados que não figuram neste calculo a subvenção kilométrica, nem a estrada de Pitanguy, nem os engenhos centraes. Os juros, Sr. presidente, de $7 \%$ sobre este capital elevão-se a 18.466:000 que terá a provincia que pagar annualmente! Mas, temos aqui, Sr. presidente, o balanço apresentado, pela repartição de fazenda, do exercicio de 81 a 82 , demonstrando que a receita ordinária neste exercicio foi de $2.764: 378 \$ 033$. E pode a provincia com esta renda insufficiente para suas despesas ordinárias, garantir juros sobre tal capital? Tenho ouvido dizer-se aqui que a receita da provincia orça-se por 4.000:000\$000. Mas, como? Tomando como renda da provincia os movimentos de fundo, as operações de credito, e a despesa a anullar? Mas como? Tomando-se como renda da provincia movimentos de fundos, as oprovações de créditos e a despeza a anullar? Eu não sei, Sr. presidende, se este medo que tenho é oriundo de minha infância! Fui empregado publico e acostumeime á cifras, acostumei-me a modelar as minhas despezas pelo orçamento de minha receita e, por isso, tenho o mao habito, de querer que a provincia modele as suas depezas pela sua receita. (Muito bem da minoria). Mas disse o deputado o Sr. Ferrraz, em uma das sessões passadas, que grande parte das concessões já estava reduzida, porque muitas dessas concessões já se achavam annuladas. Assim é; mas essas annulação não exceder a muito e aceitando a observação do nobre deputado elimino de minha conta 100.000:000\$000 ficando pois, reduzida a cifra das concessões a cifra a $163.800 .000 \$ 000$. Tiremos $7 \%$ sobre esta quantia e veremos que os juros que vão pesar sobre a provincia 
Transportes, modernização e formação regional - subsídios à história da era ferroviária ....

são ainda de 11.466.000\$00\$! Uma provincia, Sr. presidente, que não pode contar com mais de 3.222.000\$000 de sua receita, orçada alem do maximo, como fez a nobre commissão de fazenda no projeto de orçamento que se discute, podera pagar 11.466.000\$000\$ somente de juros garantidos a estradas de ferro?! E si multiplicarmos essas garantias pelo prazo dos privilegios garantidos? E os nobres deputados devem ainda attender, como já disse, que neste meu calculo não figuram as subvenções kilometricas e nem as concessões para engenhos centraes, fabricas de tecidos, como a de Montes Claros, que discutio-se ainda ha pouco, e a estrada de ferro Pitanguy. E onde iremos, Sr. presidente, onerando assim não só o presente, mas a futura geração de tão pesados encargos? Eis a bancarota da provincia ${ }^{65}$.

A distribuição geográfica das ferrovias de Minas evidencia adensamento e concentração no sul e centro, associadas à circulação de pessoas, de bens e na ligação de cidades da zona mais urbanizada. No leste, oeste e norte, por sua vez, os trilhos distribuíram-se de forma desigual e deveriam impulsionar a abertura da fronteira, a ocupação e o desenvolvimento econômico, sobretudo da cafeicultura da Zona da Mata (ver Mapa 1).

A falta de planejamento estava refletida na quase completa ausência da intermodalidade dos transportes em Minas, mormente entre as malhas ferroviária e rodoviária ${ }^{66}$. A não interligação entre as modais de transporte era agravada pelo fato de a circulação de bens e pessoas se estruturar historicamente com base nas estradas de terra.

Quanto à origem dos capitais invertidos, nota-se certa heterogeneidade. Embora relevante a presença de capitais estrangeiros, especialmente inglês e francês, e de capitais nacionais privados - principalmente nos momentos iniciais da era ferroviária -, predominaram os capitais públicos. O grau de participação destes capitais é distinto ao longo do tempo e do espaço. Os capitais estrangeiros estiveram mobilizados mais diretamente nas ferrovias voltadas à exportação, na Leopoldina Railway,

\footnotetext{
${ }^{65}$ Anais da Assembleia Provincial de Minas Gerais. Acervo do Arquivo Público Mineiro. 36a Sessão de 27/09/1883. 541p.

${ }^{66}$ PROVÍNCIA DE MINAS GERAIS. Mensagem de presidente de província e de estado. Anos de 1839, 1843, 1850, 1853 a 1870, 1887, 1892 e 1929. Disponível em: <www.crt.edu. brazil/provincial/minas_gerais>. Acesso em: 10 dez. 2009.
} 
na Vitória a Minas e na Saint John's Minning Railway ${ }^{67}$. O capital nacional atuou mais ou menos disperso e tanto em zonas voltadas ao abastecimento dos mercados de São Paulo e Rio de Janeiro, como na Sapucaí e Muzambinho, além de companhias com relativa importância na distribuição interna de bens, como na Oeste de Minas, e companhias voltadas à exportação.

O destaque coube à atuação do capital público. Iniciada com a D. Pedro II, sua participação é crescente à medida que a era ferroviária se mostra cada vez menos viável do ponto de vista econômico. De uma atuação de financiador, sob a forma dos encargos das concessões e empréstimos, o capital público torna-se agente ativo com a perenidade dos déficits e liquidações forçadas. A partir das encampações e fusões, assume também a responsabilidade administrativa e o fardo de continuar a expansão dos trilhos ${ }^{68}$.

Enquanto regra geral, o Governo Estadual assumiu a administração das companhias, enquanto o Federal arcou com gastos de encampação. Se, por um lado, o peso sobre o capital estadual pode ser percebido pelo encargo financeiro que as companhias representaram ao erário público, por outro, a responsabilidade do Governo Federal evidencia-se pela comparação entre sua atuação nas malhas de São Paulo e Minas no ano de 1912. Percebe-se claramente quão especial é o caso mineiro e quão eficiente politicamente foi a elite política regional em repassar custos ao tesouro nacional. Enquanto a malha de São Paulo estendia-se por $5.615 \mathrm{~km}$, sendo $2.012 \mathrm{~km}$, ou $35,8 \%$, de estradas de propriedade ou concedidos pelo Governo Federal, em Minas, detentora de malha de similar extensão, $5.264 \mathrm{~km}$, o Governo Federal assumiu a responsabilidade por $4.610 \mathrm{~km}$, ou $87,5 \%{ }^{69}$. Dados que demonstram um dos principais caracteres

\footnotetext{
${ }^{67}$ PIMENTA, op. cit. ESTADO DE MINAS GERAIS. Mensagem de presidente de estado. Anos de 1898 e 1913. Disponível em: <www.crt.edu.brazil/provincial/minas_gerais>. Acesso em: 10 dez. 2009.

${ }^{68}$ ESTADO DE MINAS GERAIS. Mensagem de presidente de estado. Anos de 1896 a 1898, 1902 a 1910, 1915 a 1917, 1921, 1923, 1925, 1927 a 1930. Disponível em: <www.crt.edu.brazil/ provincial/minas_gerais>. Acesso em: $10 \mathrm{dez}$. 2009. ESTADO DE MINAS GERAIS. Mensagem de presidente de estado. Belo Horizonte: Imprensa Official do Estado, 1935-1938, 1947-48.

${ }^{69}$ BRASIL. Anuário estatístico do Brasil. Rio de Janeiro: Tipografia de Estatística. 1908/1912.
} 
Transportes, modernização e formação regional - subsídios à história da era ferroviária ....

que assume a era ferroviária mineira: seu caráter antieconômico e patrimonialista.

Uma proposta de periodização para a era ferroviária mineira - A evolução da implantação dos trilhos férreos foi utilizada como variável central para a proposição de periodização (ver Gráfico 1), conquanto considerou-se também a importância da participação da esfera pública na consubstanciação desta malha, a dinâmica histórica das principais companhias ferroviárias e os eixos fundamentais que singularizam a história da era ferroviária mineira ${ }^{70}$.

São propostos seis períodos. O primeiro (1869-1878) é marcado por crescimento lento e fortemente localizado. A intensidade de trilhos assentados cresce rapidamente a partir de 1879, quando são assentados até 1898 mais de $3.200 \mathrm{~km}$ de linha. A média de avanço de trilhos franqueados por ano reduzse bruscamente a partir de 1899 e abre novo momento, com irrelevante crescimento que se estende até 1907. Observam-se, ainda, os primeiros movimentos de encampação das estradas de ferro. O período de 1908-1916 distingue-se por ativa e direta atuação da esfera pública no assentamento de trilhos. São nove anos de crescimento intenso da malha mineira, em média $271,3 \mathrm{~km}$ de trilhos/ano. Este impulso perde vitalidade e, entre 1917-1928, percebe-se atuação moderada - são $130 \mathrm{~km} /$ ano de acréscimo de linhas férreas. No sexto período, 1929-1940, esta força se esvai por completo e se torna evidente a saturação do modal ferroviário e a inclinação pelo rodoviarismo.

1869-1878 (Mapa 2) O período que se estende entre 1869-1878 marca o início do processo de modernização dos transportes em Minas, inicialmente circunscrito à região da

\footnotetext{
${ }^{70}$ Os dados foram recolhidos em RODOLPHO Jacob (Minas Geraes no $\mathbf{X X}^{\mathbf{0}}$ seculo. Rio de Janeiro: Gomes, Irmão \& C, 1911) sobre o desenvolvimento da malha ferroviária, discriminada por companhias até 1909, nas Mensagens de Presidente de Província e Estado, para o período 1840-1930 (PROVÍNCIA DE MINAS GERAIS. Mensagem de presidente de província. 1840-1888 e ESTADO DE MINAS GERAIS. Mensagem de presidente de estado. 1889-1930. Disponível em: <www.crt.edu.brazil/provincial/minas_gerais>. Acesso em: 10 dez. 2009) e diversos anos avulsos (ESTADO DE MINAS GERAIS. Mensagem de presidente de estado. Belo Horizonte: Imprensa Official do Estado, 1937, 1938, 1947 e 1948), nos Anuários Estatísticos de Minas Gerais para diversos anos (ESTADO DE MINAS GERAIS. Anuário estatístico de Minas Gerais, 1906, 1911, 1918, 1921, 1929 e 1949-53), e nos Anuários Estatísticos do Brasil para diversos anos (BRASIL. Anuário estatístico do Brasil. Rio de Janeiro: Tipografia de Estatística, 1908/1912; Tipografia do Departamento de Estatística e Publicidade, 1936 - 1937 - 1939/40; Serviço Gráfico do IBGE, 1946/52).
} 
Zona da Mata e restrito à presença de três empresas (D. Pedro II, Leopoldina e União Mineira), responsáveis pelo assentamento de $322 \mathrm{~km}$ de trilhos, com média de 35,7 km/ano. Enquanto a D. Pedro II inaugurava a estação de Sítio e assentava seus trilhos em direção a Barbacena, a Estrada de Ferro Leopoldina prolongava seus trilhos até Rio Branco e a União Mineira assentava trilhos até Mar de Hespanha.

1879 a 1898 (Mapa 3) O segundo período estende-se de 1879 a 1898 e representa continuação intensificada do movimento de expansão verificado na fase anterior. Já se nota a presença de novas companhias e o espraiamento dos trilhos para além da Zona da Mata. A extensão das estradas de ferro alcança $3.567,371 \mathrm{~km}$, tendo sido assentados em média $154 \mathrm{~km} /$ ano, durante duas décadas, e em claro sentido radial.

A malha férrea da Zona da Mata foi beneficiada tanto pelo prolongamento dos trilhos da Leopoldina, como pelo surgimento de novas companhias, entre as quais se destacam as Estradas de Ferro Juiz de Fora a Piau, Alto Muriaé e Pirapetinga. O desenvolvimento férreo na região foi da ordem de $750 \mathrm{~km}$, concentrando-se nos anos iniciais da década de 1880. A Leopoldina não respondeu por todo este crescimento, posto que encampou a maioria das companhias ainda neste período. Foi realizada comunicação entre as estradas de ferro outrora concorrentes, assim como foram construídos os prolongamentos de Pomba, Ponte Nova e Carangola.

A Estrada de Ferro Central do Brasil continuou seu prolongamento pela zona central de Minas em um movimento mais ou menos constante. Os $377,5 \mathrm{~km}$ de trilhos assentados atingiram: Barbacena, em 1880; Queluz, em 1883; Belo Horizonte, em 1895 e foi construído o ramal de Ouro Preto no ano de 1888.

O Triângulo Mineiro foi beneficiado com $281 \mathrm{~km}$ de trilhos da Mogiana, que ligaram Jaguara a Araguari e contribuíram para aprofundar a ligação da região com a economia paulista. O Leste foi beneficiado com $205 \mathrm{~km}$ da Estrada de Ferro Bahia e Minas, entre Aymorés e Teófilo Ottoni.

Foram assentados no Sul de Minas $703 \mathrm{~km}$ de linhas férreas. Aos $147 \mathrm{~km}$ da Estrada de Ferro Minas and Rio, integralmente inaugurados em 1884, foram acrescentados $349 \mathrm{~km}$ da Sapucaí e 237 km da Muzambinho. A Mogiana foi responsável 
pela construção dos ramais de Poços de Caldas e de Itapira, este se concatenando à Sapucaí.

Papel de destaque coube à zona Oeste de Minas Gerais, beneficiada pelo desenvolvimento dos $831 \mathrm{~km}$ da Estrada de Ferro Oeste de Minas. A Companhia assentou seus primeiros trilhos em 1880, entre a estação de Sítio e São João Del Rei, desenvolveu a sua linha tronco e seus ramais tributários, Itapecerica e Pitangui, além de ter construído parcialmente a linha de Formiga até Candeias e Lavras a Carrancas.

A presença de empresas ferroviárias privadas era preponderante, apenas a D. Pedro II era de propriedade imperial. Tal fato não significa que o imperativo econômico fora determinante, já que, em sua maioria, eram sustentadas por garantia de juros que oneravam fortemente o tesouro público ${ }^{71}$.

Os gastos com garantias de juros e subvenções quilométricas passam a ser motivo de preocupação crescente nas Mensagens à Assembleia. Na Mensagem de 13 de Abril de 1885, do presidente Olegário Herculano d'Aquino e Castro, pela primeira vez aborda-se o problema das Despezas com Estradas de Ferro: o gasto provincial com tal rubrica entre 2 de janeiro de 1872 e 7 de janeiro de 1885 fora de Rs. 3.572:839\$362. Gastos que se intensificaram a ponto de, em Mensagem de 13 de Abril de 1886, o presidente Herculano Portella comunicar a expedição da Lei $\mathrm{n}^{\circ} 3232$, que revogava todas as Leis que autorizavam contratos para construção de estradas ferroviárias que ainda não haviam entrado em vigor ${ }^{72}$.

Os gastos seguiram tendência ascendente assim como os trilhos assentavam-se irracionalmente. Estas duas preocupações podem ser notadas recorrentemente nas mensagens destinadas à Assembleia pelos chefes do Executivo, como, por exem-

\footnotetext{
${ }^{71}$ As empresas ferroviárias tinham o investimento financeiro como atrativo importante, seja para indivíduos isolados, seja para o capital comercial e financeiro, fosse nacional ou internacional. Como os governos (das províncias e geral) asseguravam percentual de juros sobre o capital investido, inverter capitais nas empresas ferroviárias significava ter retorno seguro, sem riscos. Para discussão dessa face da expansão ferroviária e de suas consequências, ver Flávio SAES. A grande empresa de serviços públicos na economia cafeeira, 1850-1930. São Paulo: Editora Hucitec, 1986.

${ }^{72}$ Medida necessária porque, caso todas as concessões realmente se concretizassem, a despesa do Governo Estadual em 1889 atingiria Rs. 91.934: 913\$701, recurso não disponível pelo Tesouro.
} 
plo, na mensagem de 1882 , enviada pelo presidente Theophilo Ottoni:

Tão pouco forão as concessões calcadas sobre o molde de um systema ou plano geral previamente estudado. Ao contrário, muitas emprezas forão autorisadas, muitos contratos celebrados, cada qual para determinada circumscripção, mas sem constituirem secções classificadas de um todo harmonico, planejado sobre o justo accordos das necessidades itinerantes e commerciais da Provincia. As garantias de juros e as subvenções kilometricas subirão a ponto tal, que, se todas tivessem de ser realisadas, os recursos de nosso erario e de nosso credito serião talvez insufficientes para fazer-lhes face ${ }^{73}$.

As despesas com estradas de ferro comprometeriam gravemente o Tesouro Estadual na década de 1890, após a eclosão da crise do Encilhamento, que implicou a concessão de enorme montante em empréstimos às companhias Bahia e Minas, Sapucaí, Muzambinho e Espírito Santo a Minas.

Os mecanismos que asseguravam a rentabilidade dos investimentos, por meio de subvenções, garantias de juros e empréstimos, somados ao fetiche pelas ferrovias e à inexistência de mobilização das elites mineiras por modelo de modernização dos transportes associado a projeto de desenvolvimento regional, explicam o rápido desenvolvimento da malha ferroviária neste período e nos moldes salientados. O governo vinha há muito assumindo elevada responsabilidade e ônus na modernização dos transportes. Até 1898 foram gastos Rs. 19.625:707\$771 com garantia de juros, Rs. 20.309:084\$159 com empréstimos pela Lei $n^{\circ} 64$ e Rs. 3.233:840\$000 em subvenções quilométricas. Esta despesa total de Rs. 43.168:631\$929, concentrada na década de 1890, realizou-se segundo padrão de modernização dos transportes não condizente com a estrutura econômica de Minas, ainda que compreensivel pela prevalência de um ethos essencialmente patrimonialista a orientar as elites regionais e a vigência do clientelismo a predominar nas relações entre Estado e sociedade ${ }^{74}$.

\footnotetext{
${ }^{73}$ PROVÍNCIA DE MINAS GERAIS. Mensagem de presidente de província. Ano de 1882: 40. Disponível em: <www.crt.edu.brazil/provincial/minas_gerais>. Acesso em: $10 \mathrm{dez}$. 2009.

${ }^{74}$ Sobre o sistema político da Primeira República, em geral, e sobre o caráter das elites regionais de Minas Gerais no mesmo período, em particular, ver os livros de Amílcar Vian-
} 
Transportes, modernização e formação regional - subsídios à história da era ferroviária ....

A importancia cada vez mais consideravel de interesses e capitaes empenhados nas emprezas de estradas de ferro, o numero de transações que a ellas se referem e que vão crescendo todos os dias, obriga-nos a pedir ao Governo que seja organisado um plano geral de viação ferrea n'esta provincia e que d'elle não possão afastar as concessões, para que não aconteça o que, contristada, está presenciando esta provincia. [...] Por todas essas razões e por outras muito conhecidas de V. Exc., espera esta diretoria que haja mais criterio e mais estudo nas concessões de privilegios de estradas de ferro, porque são sempre os cofres provinciaes quer direta ou indirectamente que soffrem as consequencias que provêm d'essas concessões ${ }^{75}$.

1899-1907 (Mapa 4) O terceiro período da era ferroviária mineira (1899-1907) é marcado por brusca redução da expansão no assentamento dos trilhos: o crescimento médio da malha foi de $39,5 \mathrm{~km} /$ ano, sustentado pelos $191,6 \mathrm{~km}$ da Central do Brasil, por $81 \mathrm{~km}$ da Oeste de Minas e 59,5 km da Sapucaí. Outras duas estradas que também contribuíram para a elevação da malha, mesmo que em ritmo inferior à média do período, são a Estrada de Ferro Guaxupé e a Bahia e Minas. A extensão total da malha elevou-se de $3.567,9 \mathrm{~km}$, em 1899, para 3.963,7 km, em 1907.

No período, observa-se tendência de continuidade das elevadas despesas do Governo Estadual. Os Rs. 43.168:631\$929 gastos até 1898 se transformaram em Rs. 57.122:235\$777 no ano de 1902 - sendo os empréstimos realizados pela Lei $n^{\circ} 64$ responsáveis por Rs. 15.875:412 \$015 e os juros garantidos por Rs. 24.162.191\$ 938. A despesa elevar-se-ia à Rs. 59.826: 926\$ 089 no ano de 1904.

Tendo assumido tamanha responsabilidade no desenvolvimento da malha que, como agravante, não apresentava saldos positivos de receita, decidiu-se o Governo Estadual por empreender forte política de encampação e administração direta. Deste modo, encampou e reorganizou a Estrada de Ferro Sapucaí, em 1899; encampou a Muzambinho, em 1907, e vendeu-a

na MARTINS FILHO. A economia política do café com Leite, 1900-1930. Belo Horizonte: UFMG, 1981. O segredo de Minas: a origem do estilo mineiro de fazer política. Belo Horizonte: Crisálida, 2009.

${ }^{75}$ PROVÍNCIA DE MINAS GERAIS. Mensagem de presidente de província. Ano de 1888, n. 8. Disponível em: <www.crt.edu.brazil/provincial/minas_gerais>. Acesso em: $10 \mathrm{dez}$. 2009. 
ao Governo Federal no mesmo ano. A Oeste de Minas, que entrou em liquidação forçada em 1900, é encampada diretamente pelo Governo Federal. As encampações da Minas and Rio, em 1909, e da Bahia a Minas, em 1912, se bem que não datem deste periodo, são fatos que refletem a politica aí iniciada. As principais companhias da malha ferroviária mineira ficaram, e assim permaneceram até o final do ferroviarismo, sob o domínio público.

1908 a 1916 (Mapa 5) O quarto período da modernização ferroviária em Minas, de 1908 a 1916, representa o momento do auge de euforia com o ferroviarismo. O curto período de nove anos é marcado por forte crescimento dos trilhos, que se expandem por $2.170,6 \mathrm{~km}$. Um desenvolvimento médio de impressionantes $271,3 \mathrm{~km}$ franqueados por ano, que eleva a malha a $6.288,7 \mathrm{~km}$.

Os trilhos da Oeste de Minas foram os que mais se expandiram, $517,5 \mathrm{~km}$, elevando sua malha a $1.445 \mathrm{~km}$. Seu crescimento foi realizado em duas frentes: uma, ligando Garças a Belo Horizonte, trecho construído entre 1911 e 1916, e que possibilitou a ligação das redes da Oeste de Minas e da Central do Brasil e a comunicação do oeste do estado com a capital - a mais importante ligação interna que a malha mineira realizou outra, de Carrancas a Bom Jardim, em busca do porto de Angra dos Reis.

A Estrada de Ferro Vitória a Minas assentou 385,8 km no período, tendo construído parte considerável da rede da Companhia. Seus trabalhos no território mineiro iniciaram em 1907 e, após atingirem Derrubadinha, em 1910, e alterarem seu trajeto, expandiram-se até a estação de Cachoeira Escura, em um total de $237 \mathrm{~km}$. Construiu, além disso, $148 \mathrm{~km}$ entre Curralinho e Diamantina.

A Estrada de Ferro Goiás apresentou expansão de 348 $\mathrm{km}$, dos quais $296 \mathrm{~km}$ na seção de Formiga e $52 \mathrm{~km}$ na seção de Araguari, trecho inicialmente concedido à Mogiana.

Desenvolvimentos importantes, porém de menor monta, foram realizados pela Central do Brasil, Leopoldina, Mogiana e Rede Sul-Mineira. A Central do Brasil acresceu 265,1 km à sua rede que, em 1916, já alcançava 1.157,4 Km. A Leopoldina construiu $184 \mathrm{~km}$, a Mogiana, se bem que tenha ampliado sua rede em $249 \mathrm{~km}$, o fez graças a arrendamentos junto à Sul 
Transportes, modernização e formação regional - subsídios à história da era ferroviária ....

Mineira e não propriamente por meio de expansão da malha férrea mineira. Por último, a Sul-Mineira, apesar do arrendamento concedido, ampliou sua rede em 156,4 km.

De menor extensão, foram as construções da Estrada de Ferro São Paulo e Minas, de $31 \mathrm{~km}$ entre as estações de Guardadinha e São Sebastião do Paraíso, que constituiu novo ponto de ligação entre as redes paulista e mineira, e os $8 \mathrm{~km}$ da Estrada de Ferro Morro Velho, que ligavam a mina do mesmo nome à estação de Raposos, na Central do Brasil. A ferrovia, empreendimento inglês concedido a Saint John d'El Rey Minning Company, apesar do pequeno vulto, marca o início das ferrovias especializadas no transporte de mineral.

1917-1927 (Mapa 6) Observa-se, no quinto periodo da era ferroviária mineira (1917-1927), preocupação do poder público com os modais ferroviário e rodoviário. As ferrovias expandem em ritmo relativamente mais lento, mas em movimento ainda relevante, enquanto o modal rodoviário volta à pauta de discussão nas Mensagens, ainda que subordinado ao ferroviarismo. Discute-se, inclusive, a elaboração de uma política rodoviária baseada em incentivos aos moldes das garantias de juros e subvenções quilométricas. O trecho a seguir, extraído da Mensagem do ano de 1919, do presidente Arthur Bernardes, mostra a preocupação do governo com as rodovias, como infraestrutura complementar à ferroviária:

O nosso povo, com uma percepção instinctiva das cousas realmente praticas, anceia pela locomotiva com a fé inabalável de que esse melhoramento acarretará todos os demais. Tenho para mim que o maior benefício a prestar-se ao Estado será o de estender as redes de sua viação ferrea e completa-la por meio de estradas de rodagem que lhe alimentem o trafego. Ahi está, a meu ver, a chave do nosso problema econômico. Por outro lado, num Estado central e vasto como o de Minas, cujas differentes zonas são naturalmente attrahidas para pontos diversos, impõese a comunicação facil e rapida de umas regiões com outras, por obvias razões de ordem economica e politica. [...] Preocupo-me, por isso, seriamente com o nosso problema ferroviário e hei de envidar esforços para que o Governo Federal dê maior expansão ás grandes redes existentes e continue a construção de importante ramaes já iniciados ${ }^{76}$.

${ }^{76}$ ESTADO DE MINAS GERAIS. Mensagem de presidente de estado. Belo Horizonte: Imprensa Official do Estado, 1919. p.102. 
Entretanto, é importante destacar que a fala do presidente, os dados da expansão ferroviária e a elaboração de um Plano Geral de Viação Férrea, datado de 1923, corroboram o fato de que a preocupação com o desenvolvimento ferroviário mantinha-se central na década de 1920. Elaborado por João Teixeira Soares, Olegário Maciel, Arthur Guimarães, Caetano Lopes e Ismael de Souza, o Plano Geral de Viação Férrea de 1923 abarcava dois princípios básicos:

[...] construção de linhas economicamente vantajosas e o de fazer Bello Horizonte centro da viação, de onde irradiem as vias de communicação com os pontos extremos do Estado, com as regiões productoras e com os portos de mar mais próximos [...] Cada vez mais me convenço de que estender trilhos por toda a superficie de Minas deve ser nosso escopo, nosso empenho, nossa preocupação de todas as horas 77.

A comissão afirmava, peremptoriamente, primeiro, quanto à necessidade de se modificar alguns traçados da malha existente - sem o que Minas Gerais manter-se-ia impossibilitada de contar com tráfego rápido para escoamento de sua produção e, segundo, quanto à necessidade de elaboração de um plano de viação de estradas de rodagem que complementasse o plano ferroviário.

Os dados do desenvolvimento da malha ferroviária corroboram tal perspectiva, assim como o sentido dos trilhos aponta a preocupação em fazer de Belo Horizonte o centro econômico do estado. A malha estadual que, em 1917, era de $6.354,9 \mathrm{~km}$ passaria, em 1927, a $7.921 \mathrm{~km}$; um crescimento médio da ordem de $142 \mathrm{~km} /$ ano. Mais uma vez, o destaque coube à Oeste de Minas, que atingiu $2.279,4 \mathrm{~km}$. O crescimento da rede da estrada, de propriedade federal, elevou-se não somente pela expansão dos seus trilhos pelo interior do estado, mas pela encampação de 156,4 km da Estrada de Ferro Paracatú, cuja construção iniciara em 1920, e 365 km da linha-tronco da Estrada de Ferro Goiás, entre Formiga e Patrocínio. Construiu, além de $272 \mathrm{~km}$ entre Ibiá e Uberaba, cuja concessão havia pertencido à própria Goiás, o pequeno trecho entre Campolide e Barbacena.

\footnotetext{
${ }_{77}$ ESTADO DE MINAS GERAIS, Mensagem de presidente de estado. Belo Horizonte: Imprensa Official do Estado, 1923. p. 153.
} 
Transportes, modernização e formação regional - subsídios à história da era ferroviária ....

A Central do Brasil também apresentou relevante crescimento, atingindo $1.773,8 \mathrm{~km}$. E o fez tanto pela construção de trilhos como pela encampação de estradas de outras companhias. No caso específico, foi a Bahia a Minas, de propriedade federal, que transferiu $148 \mathrm{~km}$ do trecho de Curralinho a Diamantina à Central do Brasil. Por outro lado, a Central do Brasil expandiu seus trilhos de Buenópolis a Montes Claros, prolongou alguns quilômetros no ramal de Santa Bárbara e finalizou a linha de Paraopeba, que permitia a ligação do Rio de Janeiro a Belo Horizonte sem a necessidade de baldeação na estação de Burnier.

O Sul do estado foi beneficiado não somente pela expansão dos trilhos da Rede Sul-Mineira e da Mogiana, como pelo surgimento de novas companhias. Enquanto a Mogiana foi responsável pela construção do ramal de Passos, a Rede Sul Mineira finalizou o ramal de Itajubá e inaugurou o trecho Lavras a Três Corações, conectando as redes da Oeste de Minas com a malha meridional do estado. Arrendada pelo Estado de Minas por Regulamento de setembro de 1921, a Rede Sul Mineira passou por período de intenso reaparelhamento e reorganização administrativa. A política estatal de reaparelhamento representou sensivel peso no erário público, como pode ser demonstrado pelos gastos acumulados entre os anos de 1921 e 1928: Rs. 67.771:746\$081. A extensão da Rede Sul Mineira elevar-se-ia no ano de 1929 a $1.336,8 \mathrm{~km}$, com a encampação de três novas estradas dela tributárias: i. $20 \mathrm{~km}$ da Trespontana, ii. $41,7 \mathrm{~km}$ da Machadense e iii. $31 \mathrm{~km}$ da São Gonçalo do Sapucaí.

Como destacado, a preocupação com o rodoviarismo é observada na Lei Estadual $n^{\circ} 661$, de 1915, que regulava as concessões de estradas de rodagem para automóveis e autorizava garantias de juros, e pelo Decreto $\mathrm{n}^{\circ} 4501$, de 1916. Inicialmente construídas sem planejamento, mas com ênfase à alimentação das vias férreas e fluviais, o desenvolvimento da malha tomou ímpeto e ordenamento a partir da criação da Inspectoria das Estradas de Rodagem, no ano de 1923. O Plano Viário elaborado incentivava a construção de linhas tronco que buscassem a comunicação dos principais centros regionais com Belo Horizonte e a construção de uma estrada de rodagem que comunicasse diretamente à capital federal. 
As despesas estaduais com estradas de rodagem crescem pronunciadamente no período. Até 1923 percebe-se o modesto destino de verbas às vias rodoviárias. O estado despendeu a seguintes quantias: 1911 - Rs. 203:676\$200; 1914 - Rs. 190:486\$600; 1918 - Rs. 190:395\$916; 1920 - Rs. 413:897\$934 e em 1923 - Rs. 181:042\$050. A partir da criação da Inspetoria, nota-se tendência acelerada de crescimento dos gastos: Rs. 2.583:428\$900 em 1924; Rs. 6.018:020\$000 em 1925; Rs. 13.798:207\$173 em 1926; Rs. 12.848:721\$259 em 1927. Somente de 1923 a dezembro de 1927, o Governo de Minas Gerais despendeu a soma de Rs. 35.465:419\$982. No ano de 1928, a cifra atingiria RS. 52.541:419\$382 e até 31 de dezembro de 1929, impressionantes Rs. 68.621:013\$383.

Portanto, o desenvolvimento da malha rodoviária está longe de ser irrelevante. Em 1926, era de $7.165 \mathrm{~km}$, passará, em 1927, a $11.983,8 \mathrm{~km}$, em 1928, a $12.408,7 \mathrm{~km}$ e em 1929 , a $19.413,9 \mathrm{~km}$. Este crescimento vertiginoso irá persistir na década de 1930 e consolidará o rodoviarismo enquanto principal modal de transporte em Minas Gerais na década de 1940.

1928 a 1940 (Mapa 7) A demonstração da perda de relevância do ferroviarismo pode ser percebida na comparação de sua extensão entre os anos de 1928 a 1940, sexto período da era ferroviária mineira. O crescimento foi de $254,9 \mathrm{~km}$ de trilhos, elevando a malha a $8.176 \mathrm{~km}$. As companhias responsáveis pelo crescimento da malha mineira no periodo foram: i. Vitória a Minas - que prolongou seus trilhos em direção às minas de ferro da zona central do estado; ii. Oeste de Minas - responsável pelo trecho até Monte Carmelo e até Angra dos Reis; iii. Central do Brasil que avançou seus trilhos nos ramais de Santa Bárbara, Mariana a Ponte Nova; iv. Leopoldina - que atingiu Caratinga; v. Bahia a Minas - que inaugurou as estações de Schoonor em 1930 e Araçuaí em 1940.

Os gastos públicos referentes ao ferroviarismo permaneceram crescentes mesmo neste momento final da era ferroviária. A política ferroviária adotada pelo Governo Estadual a partir de 1931, assentada no Plano da Rede Mineira de Viação, consistia em assumir a responsabilidade pela administração de todas as ferrovias pertencentes à União operantes em Minas, com exceção da Central do Brasil. Agora, para além de ser responsável 
pelos altos custos representados pelo reaparelhamento da Rede Sul Mineira, caberia ao estado a responsabilidade financeira pela Oeste de Minas, empresa permanentemente deficitária. Somente em 1953, Minas Gerais conseguiria a devolução da Rede à União.

Enquanto isso, o modal rodoviário continuava sua ascensão e, assim como o ferroviarismo, também tinha seu ônus. Mesmo com técnicas que reduziam pela metade o custo quilométrico, o Governo de Benedito Valadares elevou as despesas com a abertura de estradas: entre 1934 e 1937, a rubrica chega a Rs. 33.466:780\$000. Enquanto isso, sua extensão passa de $36.829 \mathrm{~km}$, em 1937, para $42.410 \mathrm{~km}$, em 1939. Será sob o Binômio Energia e Transporte, do Governo Juscelino Kubitschek, que o rodoviarismo assumirá definitivamente a posição de principal modal de transporte em Minas. A malha mineira, que em 1950 já se elevava a 58.959 Km, em 1954, atingirá $69.119 \mathrm{Km}$.

\section{Considerações finais}

Apesar de ser necessário considerar a dinâmica geral da economia brasileira no período, assim como as alterações que tal dinâmica engendrou - sobretudo o progressivo ganho de importância do sistema industrial e da urbanização, é indispensável que não se generalize os processos de transformações econômicas regionais e tampouco suas respectivas modernizações dos transportes. O estudo do caso de Minas Gerais aponta justamente para problemas que podem advir de generalizações.

A análise dos Inquéritos Provinciais das décadas de 18501860 e dos planos de viação de 1835, 1864 e $1871^{78}$, aponta que para a formação regional de Minas Gerais, dotada de enorme potencial de desenvolvimento, seria inadequada modernização assente exclusivamente no modal ferroviário e segundo sentido radial, portanto a requerer modernização que respeitasse suas especificidades econômicas e geográficas. Tanto é assim que, até por volta de 1880 , as políticas de modernização dos transportes pendem à priorização do modal rodoviário, em clara

${ }_{78}^{78}$ GDOY, Marcelo Magalhães e BARBOSA, Lidiany Silva. "Uma outra modernização: transportes em uma província não-exportadora - Minas Gerais, 1850-1870". Economia e Sociedade. vol.17, n.2, p. 159-186. 2008. 
sintonia com a modernização dos transportes tradicionais, ou na combinação entre múltiplas modalidades de transportes, com importante lugar para as estradas de rodagem.

A realidade que se verificou na virada do século, todavia, é distinta daquelas condições que a esfera econômica parecia requerer: em lugar de vias que facilitassem principalmente a comunicação interna e que contemplassem saídas diretas aos mais importantes mercados mineiros, faz-se realizar a modernização sob a dominância do modal ferroviário, com os trilhos voltados para fora, e em marcado desprezo pela integração do mercado interno.

A era ferroviária mineira começa com os primeiros trilhos assentados em 1869 e em 1940 já está praticamente encerrada. Marcada por seis períodos: 1869-1878, 1879-1898, 1899-1907, 1908-1916, 1917-1928 e 1929-1940, a malha mineira se tornou a maior rede ferroviária estadual do Brasil. Seus principais desenvolvimentos ocorrem durante os anos de 1879 a 1898, quando mais de $3.000 \mathrm{~km}$ são assentados, e no período que se estende de 1908 a 1916, quando são assentados mais de 2.000 $\mathrm{km}$ de trilhos. Para além do diferencial de velocidade de crescimento da malha, tais períodos se distinguem pela forma de atuação do capital público. Enquanto nos anos de 1879 a 1898 o capital público aparece com uma atuação relativamente passiva, uma vez que apenas sofre com os encargos referentes às garantias de juros, subvenções quilométricas e empréstimos, no periodo compreendido entre 1908 a 1916, sua atuação é direta e ativa, tanto enquanto proprietário de grande parte da malha como administrador de companhias ferroviárias.

Assim sendo, a era ferroviária mineira pode ser vista também enquanto importante etapa de transferência de recursos públicos para capitais privados. Primeiramente, cederam-se privilégios por demais atraentes a capitais que pouco contribuíram para o desenvolvimento de Minas; em seguida, evidenciada a incapacidade de tais capitais obterem lucros, decidiu-se pela encampação das companhias e linhas férreas. Os mais de 8.000 $\mathrm{km}$ de trilhos assentados em Minas Gerais, sem qualquer planejamento até o ano de 1923 e em claro sentido radial, não promoveram a unidade do mercado mineiro.

No final da década de 1960, o Banco de Desenvolvimento de Minas Gerais reuniu elite técnica que levou a termo amplo 
estudo da economia de Minas Gerais, intitulado Diagnóstico da Economia Mineira $^{79}$. Naturalmente, pela importância do setor de transportes para a economia, no estudo dedicou-se tópico para análise detalhada da infra-estrutura de transportes do estado ${ }^{80}$. Da avaliação do setor, destacou-se a falta de planejamento da expansão ferroviária mineira e suas consequências não virtuosas, sobretudo em relação à integração econômica regional. Além da evidente ineficiência da infraestrutura ferroviária existente, de acordo com o Diagnóstico,os centros servidos por ferrovias não dinamizaram as suas relações comerciais reciprocas. Situação que decorria de suas estruturas semelhantes e concorrentes, por não chegarem a constituir-se em núcleos razoáveis de consumo e quase sempre se orientarem para produção de bens exportáveis, funcionando como periferias de complexos aos quais se vinculavam ${ }^{81}$. O Diagnóstico ressaltava o sentido da penetração das vias férreas como um dos principais fatores na conformação de tal realidade,explicando que quase invariavelmente as linhas partiam do litoral, particularmente dos complexos guanabariano e paulista, para penetrar no território mineiro. Consequentemente, criaram tradição de trocas entre os centros industriais e aqueles polos (centros regionais de Minas Gerais).

Desvelado o cenário, o Diagnóstico indicava gama de políticas que, com implantação devidamente planejada, promoveria a articulação do sistema viário em torno de um complexo industrial interno (a região metropolitana de Belo Horizonte), moldando esse complexo às economias dos centros econômicos nacionais e também das regiões mineiras. Em sintese, segundo se projetava, as rodovias viriam não só cobrir a ineficiência da infraestrutura ferroviária, mas, sobretudo, corrigir disfunções criadas pelo modal.

O processo de modernização dos transportes, pela adoção do modal ferroviário e segundo crença de que aos trilhos associava-se de forma imanente a modernidade, atuou, para alguns, enquanto uma ilusão. Para outros, de forma interessada, enquanto vertente de ideologia do progresso, que

\footnotetext{
${ }^{79}$ Diagnóstico da Economia Mineira. Belo Horizonte: Banco de Desenvolvimento de Minas Gerais, 1968.

${ }^{80}$ Ibidem.

${ }^{81}$ Ibidem, p. 91.
} 
no caso específico, legitimaria visão de que as estradas de ferro promoveriam a modernização econômica. Tais ilusão e ideologia parecem ter se combinado para animar a atuação de importante fração da elite mineira a promover e, em alguma medida, se beneficiar, da mais dilatada expansão ferroviária do país, em momento concomitante e decisivo de intensificação do processo de perda de substância da economia regional. Quando da exaustão da era ferroviária, Minas Gerais estava prestes a assumir posição subordinada na divisão inter-regional do trabalho, cabendo ao rodoviarismo consolidar a posição periférica do estado no âmbito da economia nacional.

\section{Anexo - Gráfico e mapas da evolução da malha ferroviária mineira, 1867-1940}

Gráfico 1: Evolução da malha ferroviária mineira: $1867-1953$

Fonte: Jacob (1911), Província de Minas, 1867-1888, Estado de Minas, 1889-1930, 1949-52.

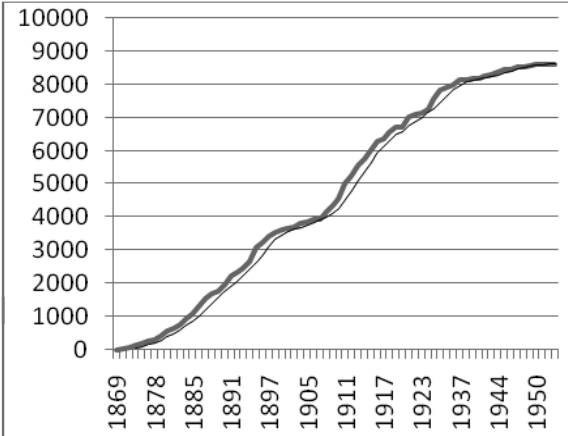

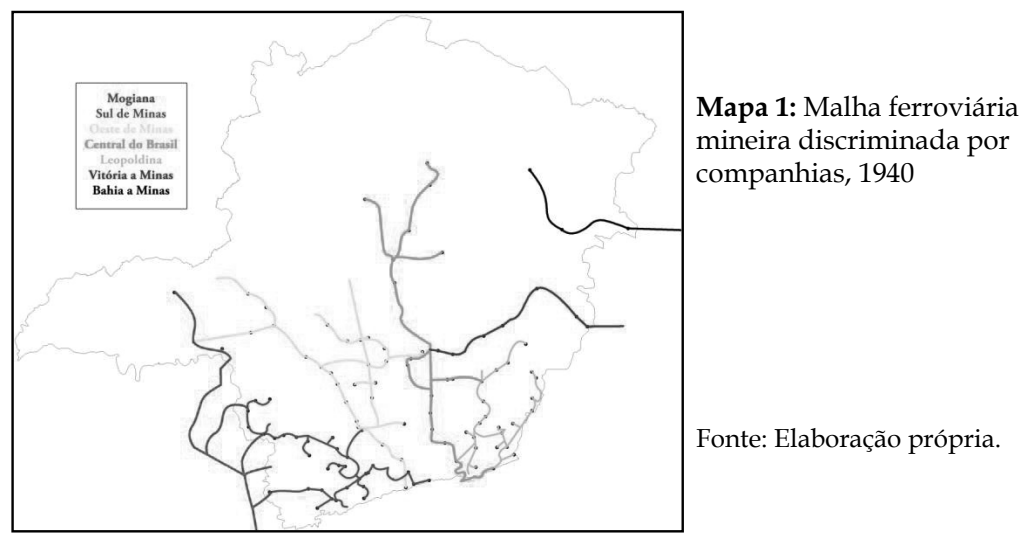


Transportes, modernização e formação regional - subsídios à história da era ferroviária ....

Mapa 2: Evolução da malha ferroviária mineira: $1867-1878$

Fonte: Elaboração própria.
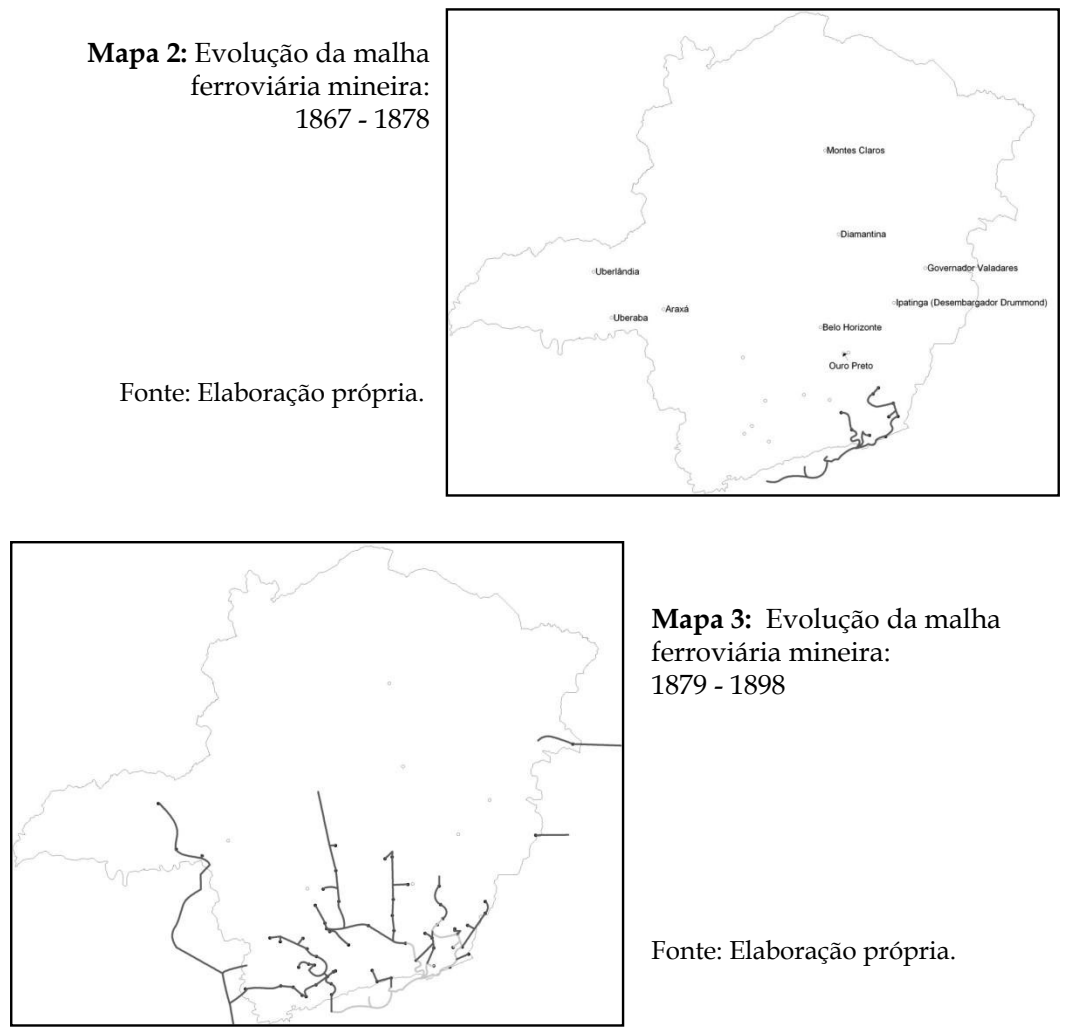

Mapa 3: Evolução da malha ferroviária mineira: 1879 - 1898

Fonte: Elaboração própria.

Mapa 4: Evolução da malha ferroviária mineira: 1899 - 1907

Fonte: Elaboração própria.

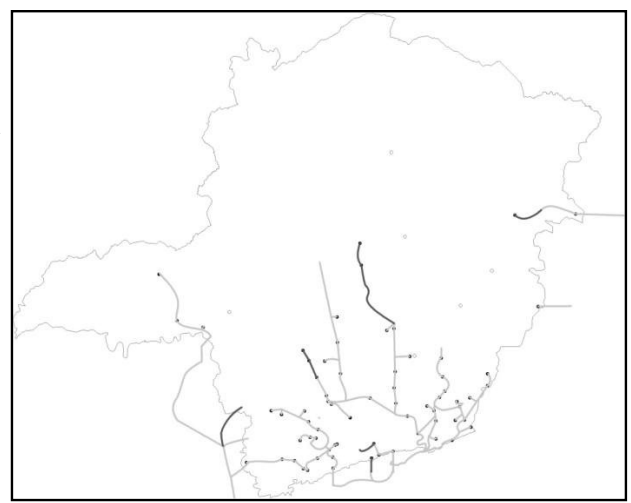


Felipe Alvarenga Batista, Lidiany Silva Barbosa; Marcelo Magalhães Godoy

Mapa 5: Evolução da malha ferroviária mineira: $1908-1916$

Fonte: Elaboração própria.
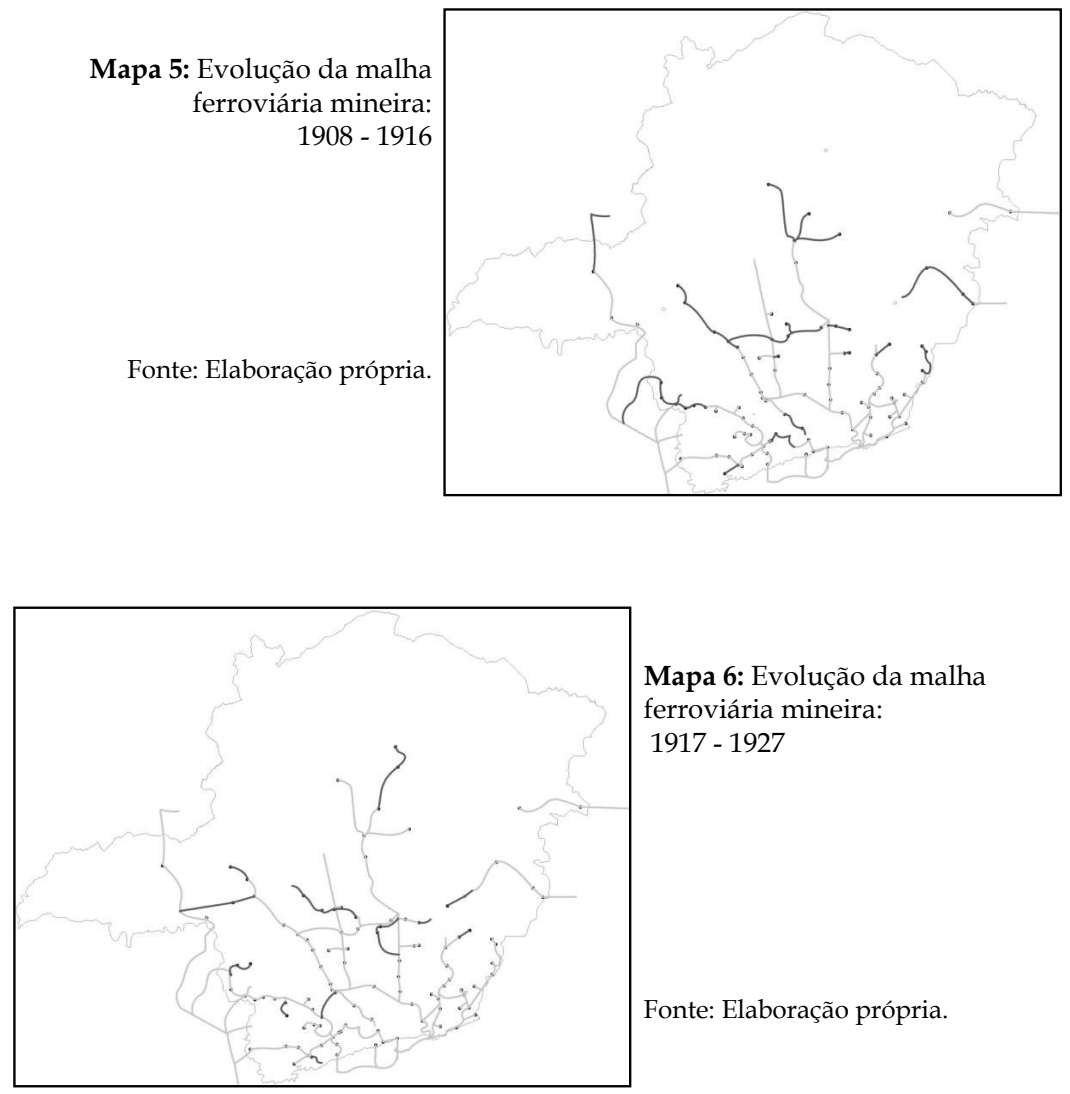

Mapa 6: Evolução da malha ferroviária mineira: 1917 - 1927

Fonte: Elaboração própria.

Fonte: Elaboração própria.

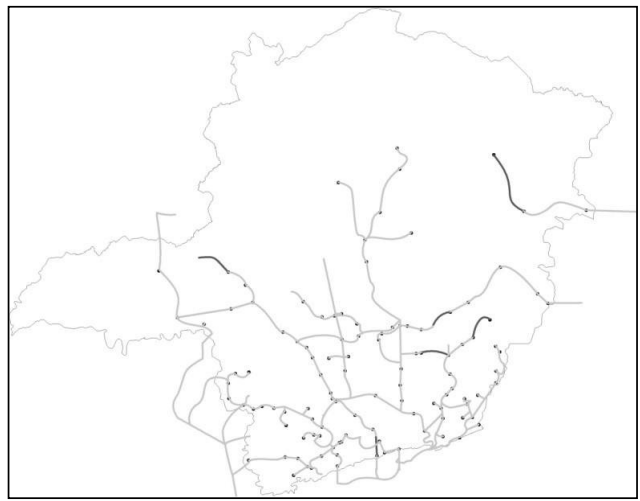


Transportes, modernização e formação regional - subsídios à história da era ferroviária ....

Resumo: $O$ estudo aborda o processo de modernização ferroviária de Minas Gerais. Adota-se enquadramento teórico que combina variáveis externas, em especial a expansão do capital na periferia, com internas, sobretudo a hegemonia de modelo econômico primário-exportador em realidade nacional, marcada por pronunciada diversidade regional. Constatou-se que a inadequação do padrão de modernização ferroviária dominante no país em relação à estrutura da economia mineira não impediu que, contraditoriamente, a expansão dos trilhos alcançasse a maior extensão do Brasil no território de Minas Gerais. Fatores políticos e financeiros presidiram a febre ferroviária mineira, conquanto contemporâneos tenham sublinhado o caráter irracional, oneroso e disfuncional que se imprimiu ao sistema de concessão, subsídios públicos e manutenção pelo Estado da rede regional. No plano ideológico, mobilizou-se associação supostamente legitimadora entre ferrovias e modernidade. Substantivamente, contemplam-se elementos da história das companhias de estradas de ferro com atuação em Minas Gerais, bem como se propõe periodização para a era ferroviária mineira, acompanhada da sistematização em bases cartográficas do processo de expansão da malha.

Palavras-chave: Transportes. Modernização. Era ferroviária. Minas Gerais, 1870-1940.

Abstract:This study examines the process of railway modernization in the State of Minas Gerais, Brazil. It uses theoretical classification that combines external variables, especially the expansion of the capital towards the periphery, with internal variables, above all the hegemony of the raw material exporting model, marked by a strong regional diversity. It was noted that the inadequacy of the dominant pattern of railway modernization in Brazil in relation to the economic structure of Minas did not prevent the expansion of the tracks from reaching its greatest length in the territory of this State. Political and financial factors presided over the Minas railway fever, which, in spite of being contemporary, underlined the irrational, onerous and dysfunctional nature of the system of concession, public subsidies and maintenance by the State of the regional network. On the ideological level, a supposedly legitimating association was fostered between railways and modernity. On the substantive level, our work covers elements of the history of railway companies that were active in Minas Gerais, while also proposing a time period to comprise the Minas railway age, accompanied by a cartographic based systematization of the expansion process of the railway network.

Keywords: Transportation. Modernization. Railway age. Minas Gerais, 1870-1940.

Artigo recebido em 12/04/2012

Artigo aprovado para publicação em 22/06/2012 